\title{
Data Mining and Machine Learning Approaches in Designing Optimum Drug Delivery Systems: A Prototype Study of Niosomes
}

Aliasgar Shahiwala ( $\square$ alishahiwala@gmail.com )

Dubai Pharmacy College for Girls

Nuruzzaman Faruqui

Jahangirnagar University

Samar Salam Qawoogha

Dubai Pharmacy College for Girls

\section{Research Article}

Keywords: Data mining, Artificial Neural Networks, Niosomes, Entrapment Efficiency, Particle Size,

Donepezil $\mathrm{HCl}$

Posted Date: August 7th, 2021

DOI: https://doi.org/10.21203/rs.3.rs-778144/v1

License: (9) This work is licensed under a Creative Commons Attribution 4.0 International License. Read Full License 
Data Mining and Machine Learning Approaches in Designing Optimum Drug Delivery Systems: A Prototype Study of Niosomes

Samar Salam Qawoogha ${ }^{1}$, Nuruzzaman Faruqui ${ }^{2}$, AliasgarShahiwala ${ }^{1^{*}}$

${ }^{1}$ Dubai Pharmacy College for Girls, Dubai, United Arab Emirates

${ }^{2}$ Institute of Information Technology, Jahangirnagar University, Dhaka, Bangladesh

\section{Address for Correspondence:}

Aliasgar Shahiwala, Professor, Department of Pharmaceutics

Dubai Pharmacy College for Girls. Phone (o): + 9714 2120303, mobile: + 971552563898.

email: alishahiwala@gmail.com; dr.asgar@dpc.edu 


\begin{abstract}
:
This study aims to model the prediction of two clinically relevant properties of drug delivery systems specifically for niosomes, i.e., particle size and drug entrapment efficiency (EE\%) using a combined approach of data mining, artificial neural networks (ANN), and design of experiments (DoE). Preferred Reporting Items for Systematic Reviews and Meta-Analyses (PRISMA) system was adopted to screen published literature on niosomes that resulted in 17 articles with 114 formulations. Eleven properties (input parameters) related to drugs and niosomes affecting particle size and drug entrapment (EE\%) (output variables) were precisely identified and used for the network training. The network architecture consists of 5 fully connected hidden layers with eleven hidden nodes in each layer, input layer has eleven nodes where each of these nodes maintains omnidirectional injective relation with the corresponding hidden node. The hyperbolic tangent sigmoid transfer function (HTSTF) with LevenbergMarquardt backpropagation (LMB) was used to train the model. The network showed the highest prediction accuracy of $93.76 \%$ and $91.79 \%$ for EE\% and particle size prediction. Sensitivity analysis identified drug/lipid ratio and Cholesterol/Surfactant ratio as the most significant factors affecting EE\% and particle size of niosomes. Accordingly, nine Donepezil hydrochloride (DNPZ) noisome batches were prepared using a 3x3 factorial design with drug/lipid ratio and cholesterol/surfactant ratio as factors to validate the developed model for a new drug. The model was able to reach a prediction accuracy of more than $97 \%$ for experimental batches. Finally, the superiority of global ANN was demonstrated compared to the local RSM model for DNPZ niosome formulations. In conclusion, this study has demonstrated the use of the data mining approach to group published scattered information and formulate a data set to train the ANN that can help to design an optimum formulation and processing parameters for a clinically viable medicine with minimum time, cost, and efforts. However, the key challenge in forming an efficient ANN lies in having a suitable large data set and using the correct algorithm for the network.
\end{abstract}

Keywords: Data mining, Artificial Neural Networks, Niosomes, Entrapment Efficiency, Particle Size, Donepezil HCl. 


\section{Graphical Abstract:}

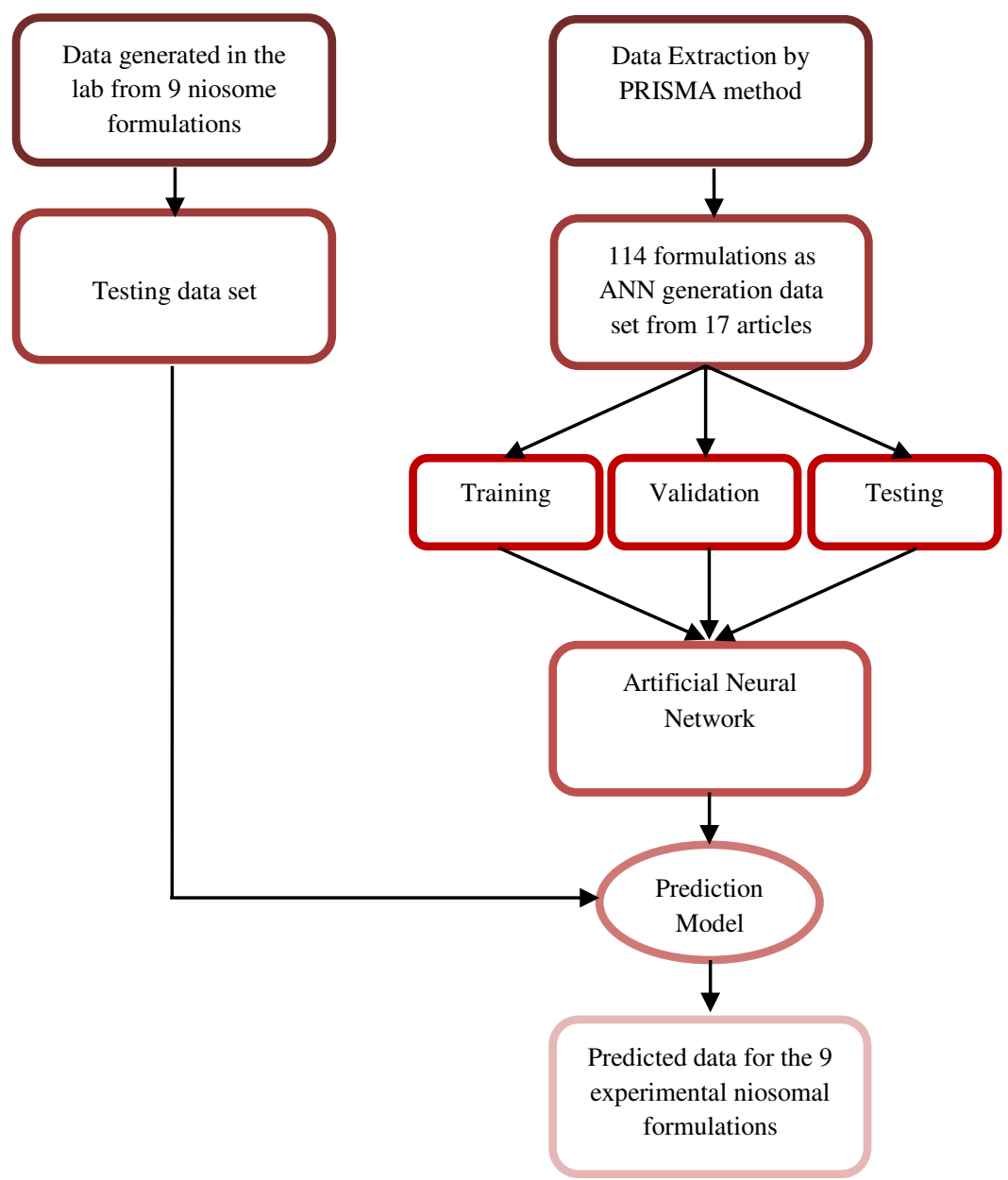




\section{Introduction}

In 2005, the concept of Quality by design (QbD) was defined in the International Conference on Harmonization ( $\mathrm{ICH})$ Q8 guideline as a systematic, science-based approach to pharmaceutical drug development and manufacturing in the pharmaceutical industry ${ }^{1}$. The advantages of using the QbD principles are having a successful product development, followed by a prompt regulatory approval, a decrease in the validation burden as well as post-approval changes ${ }^{2}$. QbD consists of several elements. These elements include a quality target product profile (QTPP) with well-defined critical quality attributes (CQAs); critical material attributes (CMAs); a process design and understanding that includes the identification of critical process parameters (CPPs); linking CMAs and CPPs to CQAs; a control strategy that includes specifications for the drug substance(s), excipient(s), and drug product as well as controls for each step of the manufacturing process; and process capability and continual improvement. QbD has also several tools and studies which include: prior knowledge, mechanistic models, risk assessment, process analytical technology (PAT) and design of experiments (DoE), and data analysis ${ }^{3}$.

DoE, especially the factorial design was used in solid dosage forms development in the 1980s. The use of such tools helped in identifying critical process parameters of complex processes, in addition to improving and optimizing formulations. Response Surface Methodology (RSM) was found to be the most popular optimization technique which uses polynomial equation(s) as a mathematical description linking and displaying the relationship between responses "outputs" to inputs: $\mathrm{y}=\mathrm{f}\left(\mathrm{x}_{1}, \mathrm{x}_{2}, \ldots, \mathrm{x}_{\mathrm{q}}\right)+\mathrm{e}$ where $\mathrm{x}_{1}, \mathrm{x}_{2}, \ldots, \mathrm{x}_{\mathrm{q}}$ are inputs and $\mathrm{y}$ is the response. Although using such a technique is advantageous as it is easy to use and not requiring the knowledge of the true linkage between the inputs and outputs, using such a model could occasionally result in a poor estimation of optimal conditions as input and output relationships ${ }^{4}$.

Over the past few years Artificial intelligence (AI) and machine learning (ML) in particular, have experienced a significant interest in various fields, including drug delivery system design. These include the development and optimization of oral disintegrating tablets ${ }^{5}$, nanosuspension ${ }^{6}$, hard gelatin capsules ${ }^{7}$, nanofibers ${ }^{8}$, nanoparticles ${ }^{9}$, etc. Combining machine learning tools, such as ANNs along with DoE could be a better approach to define and control the design space. DoE helps in setting up the levels and boundaries of the factors that influence CQAs. DoE is mainly based on simple polynomial models that often fail for higher non-linear relationships that 
exist between causal factors and outcome variables. ANNs are advanced modeling techniques that offer a diverse variety of classification and modeling techniques that are required for nonlinear modeling of the data ${ }^{10}$. Combining machine learning tools, such as ANNs along with DoE could be a better approach to define and control the design space.

Niosomes, bilayer vesicles formed by self-assembly of mainly nonionic surfactants and cholesterol, are one of the most promising and have been extensively studied nanocarriers for drug delivery and targeting applications and have shown greater physicochemical stability as well as a reduced production cost in comparison to liposomes ${ }^{11,12}$. Due to their biocompatible, biodegradable, non-immunogenic nature with high stability and ability to deliver drugs at a desired site in the body in a controlled manner, it is no surprise that over 50,000 research articles have been published on niosomes ${ }^{13,14}$. Such a vast amount of data can serve to identify the trends, relationships, and making future predictions possible. However, unlike other fields, the data mining approach is not properly utilized in drug delivery research. The main reason for this could be that the required information is scattered in publications that need manual intervention to collect the data, group the data, and converting raw data to clean data, which is a timeconsuming and very demanding task.

Recently, data mining has become a very important research direction in the field of drug discovery to design a new biologically active compound based on previously synthesized molecules and from established quantitative structure-activity relationships ${ }^{15}$. Data mining is knowledge discovery from a large amount of data, which helps to discover patterns in improving the quality of delivery methods ${ }^{16}$. This study demonstrates a data mining approach to extract useful data from the published studies on niosomes, followed by using ANN to develop a mathematical model capable of predicting two clinically important CQAs of niosomes, i.e., particle size and entrapment efficiency (EE\%). In contrast to other published pharmaceutical research that use their experimental values to train the ANN to predict formulation parameters ${ }^{17-}$ 21, we have built our ANN prediction model from the published literature. Hence, we aim to show the importance of utilizing published literature information in the field of drug delivery research and advances in machine learning to transform the future of the pharmaceutical industrial field.

To achieve this goal, niosome properties affecting particle size and EE\% were precisely 
identified, collected from previously published articles of various drugs, quantified, and then used as an input dataset for the model. Finally, the model was trained, validated and, tested comprehensively against data located inside and outside the borders used to train it. Furthermore, the evaluation of the established model involved a testing dataset of a completely new drug Donepezil hydrochloride (DNPZ) that is not present in the dataset used to form the prediction model. DNPZ is indicated for the symptomatic treatment of mild to moderate Alzheimer's disease $^{22}$.

\section{Materials and Methods}

\subsection{Materials}

Donepezil HCl (DNPZ) was a kind gift from Neopharma Pharmaceutical Industries, Abu Dhabi, United Arab Emirates. Cholesterol (CHOL), potassium dihydrogen phosphate $\left(\mathrm{KH}_{2} \mathrm{PO}_{4}\right)$, potassium chloride $(\mathrm{KCl})$, sodium chloride $(\mathrm{NaCl})$, disodium phosphate $\left(\mathrm{Na}_{2} \mathrm{HPO}_{4}\right)$, and sorbitan monostearate (Span 60®) were bought from Sigma-Aldrich, United Kingdom. All other chemicals and solvents were of analytical grade.

\subsection{Methods}

\subsubsection{Extraction of data from published literature to form a data set}

The data extraction for this study was performed manually from selected research articles that fit our inclusion criteria. An initial database search was conducted in October 2020 returned 49 articles from the PubMed database and 114 articles from Google Scholar. Both Google Scholar and PubMed were accessed using the search criteria containing the following keywords: (((Niosomes[Text]) AND (span 60[Text])) AND (film hydration [Text Word])). The articles were all imported into Mendeley (version 1.19.2) bibliography management software (Mendeley Ltd). The articles were screened according to our inclusion and exclusion criteria and identified 17 eligible articles. The inclusion criteria for the initial search included all literature, full texts, and abstracts in English in the timeframe of the past 15 years (i.e., literature published between 2006 till present). The article selection process was conducted following the Preferred Reporting

Items for Systematic Reviews and Meta-Analyses (PRISMA) system and is outlined in detail in Figure 1. Following the identification of relevant articles, each article was screened manually to 
exclude articles that do not contain the values of all the required parameters in the data set ending up with 17 articles. The authors have read the full text of the 17 articles and extracted the data. The dataset obtained from the selected 17 articles is presented in Appendix A.

The dataset used to train the network was collected from various published noisome articles making a total of 114 different samples from 17 niosomal drug formulations ${ }^{23,24,33-39,25-32}$. Due to the variety of niosome preparation methods are available, we have chosen the articles involving the thin-film hydration (TFH) method, which is one of the widely used methods for niosome preparation. The collected data present in Appendix A was then fed to the software to train the network and form the prediction model. Eleven parameters including molecular weight $(\mathrm{g} / \mathrm{mol}), \log \mathrm{P}$, solubility in water $(\mathrm{mg} / \mathrm{ml})$, PKA, hydration media amount $(\mathrm{ml})$, solvent amount (ml), HLB, drug/lipid ratio, chol/ surf molar ratio, time of hydration and temp of hydration were taken as input parameters for ANN training with the output to be \%EE and particle size hydrodynamic diameter.

\subsubsection{ANN Model Development}

The ANN analysis was developed using MATLAB R2019b software to build a prediction ANN model and model the complex nonlinear relation between inputs and outputs. Two function fitting neural networks (fitnet) have been used in this experiment to predict the \%EE and particle size hydrodynamic diameter. Each of these networks has the same architecture. It consists of 5 fully connected hidden layers with eleven hidden nodes in each layer. The input layer has eleven nodes where each of these nodes maintains omnidirectional injective relation with the corresponding hidden node. The output layer has one output node. The activation function for hidden nodes as well as for the output node is the hyperbolic tangent sigmoid transfer function (HTSTF) ${ }^{40}$. The bias of the hidden nodes along with the output node is 1 . In this network, 561 weight elements have been used. The weights are initialized by the Nguyen-Widrow layer initialization function ${ }^{41}$. The network architecture ignoring the input layer is defined by (1) as follows:

$$
\text { Output }=f_{H T S T}\left(\sum_{i=1}^{5} \sum_{j=1}^{10} f_{H T S T}\left(\left(N_{i j} \times W_{i j}\right)+b_{i}\right)\right)
$$

Here, $i=$ hidden layer index $j=$ hidden layer node index,$N=$ node, $W=$ weight, $b=$ bias, $f_{H T S T}=$ Hyperbolic tangent sigmoid transfer function 
The Levenberg-Marquardt backpropagation algorithm was used for this investigation ${ }^{42}$. The purpose of using this algorithm was to avoid the Hessian matrix calculation and approximate it from the Jacobian matrix ${ }^{43}$. It contains the first-order derivative of the network error. Moreover, it is possible to compute it through a regular backpropagation algorithm which is computationally less expensive ${ }^{43}$. Equation 2 governs the weight update of the network as follows:

$$
W_{j+1}=W_{j}-\left[J^{T} J+\mu I\right]^{-1} J^{T} e
$$

Where $\mathrm{W}_{\mathrm{j}+1}$ is the update weight, $\mathrm{W}_{\mathrm{j}}$ is updating weight, $\mathrm{J}^{\mathrm{T}} \mathrm{J}$ is the Hessian matrix approximation, $\mu$ a scalar parameter to control the transition to Newton's method ${ }^{44}$ and $\mathrm{e}$ is the network error vector.

The training dataset is randomly divided into training, validation, and testing data by maintaining a 7:1.5:1.5 relation. The random division treats every sample exclusively. Because of using Jacobians for error vectors, the training performance can be evaluated using either mean squared error (MSE) or sum squared error (SSE). In this experiment, the MSE has been used as a performance measurement function which is defined by equation 3 .

$$
M S E=\frac{1}{n} \sum_{i=1}^{n}\left(y_{i}-\widetilde{y}_{l}\right)^{2}
$$

Here where $y_{i}$ are the observed values and $\widetilde{y}_{l}$ are the predicted values and $n$ is the number of experiments $(n=9)$.

The algorithm steps of the weight update process are mentioned as follows:

$$
\begin{aligned}
& \text { Step 1: if }\left(\frac{\delta}{\delta w}(\text { weight }) \wedge \frac{\delta}{\delta n}\left(\text { net }_{\text {input }}\right) \wedge \frac{\delta}{\delta w}\left(\text { transfer }_{\text {function }}\right)\right)==\text { valid } \\
& \text { Step 1.1: } \quad \text { while }(\text { epochs }<\text { limit } \wedge \text { time }<\max \text { time } \wedge \text { performance } ¥ \\
& \text { goal } \left.\wedge \text { gradient }>\text { gradient }_{\min } \wedge m u<m u_{\text {max }}\right) \\
& \text { Step 1.1.1: jacobian } \leftarrow \text { Backpropagation(Weight, Bias) } \\
& \text { Step } \quad \text { 1.1.2: } \quad \text { weight } t_{\text {update }} \leftarrow(-(\text { jacobian } * \text { jacobian })+I * \\
& \text { mu)/(jacobian * errors) } \\
& \text { Step 1.1.3: weight } \text { updated }_{\text {weight }} \leftarrow \text { wpdated }_{\text {weight }}+\text { wpdate }_{\text {und }}
\end{aligned}
$$

Step 2: else terminate the program 
The output of the algorithm is the weight update which trains the network to predict with better accuracy in the next iteration.

\subsubsection{Sensitivity analysis of the model}

For the analysis of the importance of formulation and processing parameters, the model was trained, again and again, withdrawing one input variable each time while keeping remaining variables as it is. The standard deviation in the output values of the model was calculated for each input variable change assigned as the sensitivity of the model ${ }^{19}$.

\subsubsection{ANN Model Testing}

Nine formulations of DNPZ-loaded niosomes were designed using 3x3 factorial design containing different surfactants and different surfactant:cholesterol molar ratios as depicted in Table 1. Niosomes were prepared by TFH where 10mg of DNPZ and a mixture of Span60 and cholesterol in different molar ratios were dissolved in $10 \mathrm{ml}$ chloroform and methanol (2:1) in a $500 \mathrm{ml}$ rounded-bottom flask to obtain a clear solution. The organic solvent was removed at $55^{\circ} \mathrm{C}$ (above the phase transition temperature, $\mathrm{T}_{\mathrm{c}}=53 \pm 0.5^{\circ} \mathrm{C}$ [64]) under reduced pressure on a rotary evaporator (Heidolph Laborota 4000 efficient, Germany) at $150 \mathrm{rpm}$ to form a thin film on the flask wall. The obtained dried lipid film was hydrated with $10 \mathrm{ml}$ of phosphate buffer solution (PBS, pH 7.4) by rotating in a water bath at $55^{\circ} \mathrm{C}$ for about $1 \mathrm{~h}$ to form white milky niosomal dispersion. The resulting multilamellar vesicle dispersion was stabilized by placing them in the refrigerator at $4 \pm 2^{\circ} \mathrm{C}$ for 24 hours before being further subjected to characterizations.

To determine drug entrapment, $0.1 \mathrm{ml}$ of DNPZ suspension was diluted with $10 \mathrm{ml}$ of methanol to obtain a clear solution. The concentration of entrapped DNPZ was determined spectrophotometrically at $268 \mathrm{~nm}$ using a UV spectrophotometer (UV-1700, Pharma Spec, Shimadzu, Japan) after separation of niosomes from free drug using centrifugation (Unicen, Orto Alresa, Madrid, Spain.) at 4,000 rpm for 5 min then treated similarly. The entrapment efficiency was determined relative to the original drug concentration as $\mathrm{EE} \%=\mathrm{ED} / \mathrm{TD} * 100$, where $\mathrm{EE} \%$ is the entrapment efficiency percent, ED is the entrapped drug concentration and TD is the

theoretical drug concentration ${ }^{32}$. The particle size of DNPZ niosomes was measured by Litesizer $^{\mathrm{TM}} 500$ (Anton Paar $\mathrm{GmbH}$, Graz, Austria). A $0.3 \mathrm{ml}$ of the niosomal suspension was added to $10 \mathrm{ml}$ of phosphate buffer solution (PBS, $\mathrm{pH} 7.4$ ) then $1 \mathrm{ml}$ of this mixture was taken to 
be added into the device cuvette to start the measurement. Each measurement was done in triplicate.

The testing data set present in table 1 was fed into the generated ANN prediction model in the software to obtain the predicted result of $\% \mathrm{EE}$ and particle size diameter of the experimental DNPZ formulations. The model predicted and experimental values were compared for all the nine DNPZ formulations using paired t-test (IBM SPSS $®$ statistics version 20, USA) to determine statistically significant differences at a significance level of $\mathrm{p}<0.05$.

\subsubsection{RSM vs ANN comparison}

Prepared DNPZ niosomal formulations prepared using $3^{2}$ factorial design were fitted into the quadratic polynomial model by regression analysis to compare its prediction accuracy against the ANN model.

\section{Results and Discussion:}

\subsection{ANN Prediction Model Performance and Accuracy}

The network defined by (Figure 2) has been deployed twice for \%EE and particle size diameter prediction. It has been implemented in MATLAB R2019B version running in Windows 1064 bit operating system with a primary memory of 8 GB powered by an Intel Core i5 processor with a maximum $3.7 \mathrm{GHz}$ clock speed. Although the network has been primarily designed to use the Levenberg-Marquardt backpropagation (LMB) algorithm, to demonstrate the comparative study and justify the reason for electing the LBM as the learning rule, 5 other backpropagation algorithms which are tabulated in table $\mathbf{2}$ and $\mathbf{3}$ have been used in this experiment. Table 2 contains the EE\%-related data and table 3 contains the particle size diameter-related data. The set of parameters that have been examined to evaluate the performance of the network are training time, mean square errors (MSE) of testing, validation, training, and prediction accuracy.

Both the results depicted in table 3 and table 4 justifies the use of (LMB) algorithm as the learning rule for the ANN prediction model. LMB scored the highest prediction accuracy of 93.76\% and a relatively low MSE of 25.7657 for \%EE prediction, and it scored the highest prediction accuracy of $91.7910 \%$ and the lowest MSE of 64.5089 for Particle Size Prediction. The (LMB) algorithm has also scored the highest $\mathrm{R}^{2}$-value in comparison to the other algorithms 
as shown in figure 3 scoring an $\mathrm{R}^{2}$-value of 0.9709 for $\% \mathrm{EE}$ and an $\mathrm{R}^{2}$-value of 1 in figure $\mathbf{4}$ for particle size.

\subsection{Sensitivity analysis}

The outcome of sensitivity analysis is shown in figure 5. Input variables include 1 surfactant descriptor (HLB), 4 drug-related descriptors (Molecular weight, Log P, Solubility in water, and pKa), 4 formulation variables (hydration media amount, solvent amount, drug/lipid ratio, Chol/Span 60 ratio) and 2 processing parameters (time of hydration and temperature of hydration). Sensitivity analysis revealed that drug/lipid ratio and Chol/Span60 ratio have the highest impact on both \%EE and particle size of the niosomes. Comparing other variables drug and surfactant-related descriptors have more effect on $\% \mathrm{EE}$ while processing parameters (time and temperature of hydration) play a more significant role in determining the particle size of the niosomes.

\subsection{DNPZ Formulation and Characterization:}

Based on sensitivity analysis, drug/lipid ratio and Chol/Span60 ratio were the most significant factors affecting the particle size and \%EE. Hence, nine DNPZ formulations were designed using $3^{2}$ factorial design altering drug/lipid ratio and Chol/Span60 ratio, while keeping other formulation and processing variables the same. Drug descriptors for DNPZ were taken as reported in the literature to feed in the network.

DNPZ niosomal formulations showed an entrapment efficiency percentage ranging from 98.00 \pm 0.49 to $79.08 \pm 0.50$ while the size of the prepared vesicles was in the range $475.47 \pm 43.43 \mathrm{~nm}$ to $2507.33 \pm 79.88 \mathrm{~nm}$ as shown in Table 4, providing a relatively wider range to test the ANN prediction accuracy.

\subsection{The ANN model predictions}

After forming the ANN prediction model as shown in Figure 2 and checking the performance and accuracy of the artificial neural network using the LMB algorithm, the model was introduced to unobserved data which is the testing dataset in Table 1 containing the 9 formulations of DNPZ niosomes. The model was run for \% EE and particle size diameter prediction separately. 
The model predicted and experimental values for the DNPZ noisome formulations (F1-F9) along with the $\%$ prediction accuracy of the model are presented in Table 4. The ANN model predicted values for this study were in close agreement with the observed values for the test formulations. The model was able to reach a \%EE prediction accuracy of $99.38 \%$ and a particle size prediction accuracy of $97.12 \%$. However, the highest observed prediction error for \%EE was $6.86 \%$ while for particle size it was $60.91 \%$ thus the prediction model was more efficient in predicting the $\%$ EE data than the particle size. This reflects that the network needs more particle size training data to give better future results. A Paired-samples t-test was also conducted to check for any significant differences between the experimental and ANN predicted values exist. No significant differences between the experimental values $(\mathrm{M}=89.34, \mathrm{SD}=6.23)$ and $\mathrm{ANN}$ predicted values $(\mathrm{M}=89.01, \mathrm{SD}=5.21) ; \mathrm{t}(8)=0.3383, \mathrm{p}=0.7438$ for $\mathrm{EE} \%$ were found. Similar results were obtained for the actual particle size $(\mathrm{M}=1372.02, \mathrm{SD}=744.08)$ and $\mathrm{ANN}$ predicted particle size values $(\mathrm{M}=1414.45, \mathrm{SD}=641.84) ; \mathrm{t}(8)=0.4704, \mathrm{p}=0.6506$.

\subsection{Comparison between local RSM vs global ANN}

The prediction capabilities of local RSM were compared to ANN models for the coefficient of correlation determination $\left(\mathrm{R}^{2}\right)$, mean square error (MSE), and root mean square error (RMSE).

Table 5 shows that the model P-value is not significant and the Model F-value of 7.17 implies there is a $6.78 \%$ chance that an F-value this large could occur due to noise; therefore, the model cannot be used to predict \%EE results. However, the model P-value is significant for particle size and the model was used to predict particle size results and comparison against particle size prediction by ANN. The results of particle size predictions showed the superiority of ANN in comparison to the RSM method (Table 6). ANN scored a higher $\mathrm{R}^{2}$ value of 0.994 in comparison to the RSM $\mathrm{R}^{2}$ value of 0.992 . Additionally, ANN had significantly lower MSE=66873 and $\mathrm{RMSE}=258.6$ than the RSM method MSE=105429 and RMSE=324.7.

\section{Conclusion and Future Prospects}

Thousands of published literature on nanocarriers-based drug delivery formulations are present to the public every year. Such a data set can form and train an artificial neural network prediction model for formula parameters and displays promising results against the traditional laborious time consuming "trial-and-error" method. Furthermore, the ANN approach is found to be 
superior to other QbD approaches since it can form network connections between non-linear complex data that follow no specific experiment design as compared to the RSM DoE approach. This paper has demonstrated the use of the data mining approach to group published scattered information and formulate a data set that can be used to train the ANN that can help to select the optimum formulation and processing parameters for clinically desired properties of a formulation. However, the key challenge in forming an efficient ANN lies in having a suitable large data set and using the correct algorithm for the network. Authors strongly suggest that we should not lose the wealth of data available and need to thoroughly utilize them for machine learning which in turn result in better predictions for designing better medicines with less cost, materials, and time.

\section{Acknowledgment}

The authors would like to thank Dubai Pharmacy College for Girls, for providing the necessary facilities for carrying out this investigation.

\section{Ethics declarations: Conflict of Interest}

The authors declare no conflicts of interest during the writing of this article.

\section{References}

1. Abraham, J. International conference on harmonisation of technical requirements for registration of pharmaceuticals for human use. in Handbook of Transnational Economic Governance Regimes 1041-1053 (2009). doi:10.1163/ej.9789004163300.i-1081.

2. Pramod, K., Tahir, Ma., Charoo, N., Ansari, S. \& Ali, J. Pharmaceutical product development: A quality by design approach. Int. J. Pharm. Investig. 6, 129 (2016).

3. Yu, L. X. et al. Understanding pharmaceutical quality by design. AAPS Journal vol. 16 771-783 (2014).

4. Lewis, G. A., Mathieu, D. \& Phan-Tan-Luu, R. Pharmaceutical Experimental Design. Pharmaceutical Experimental Design (CRC Press, 1998). doi:10.1201/9780203508688.

5. Han, R., Yang, Y., Li, X. \& Ouyang, D. Predicting oral disintegrating tablet formulations by neural network techniques. Asian J. Pharm. Sci. 13, 336-342 (2018).

6. Aghajani, M., Shahverdi, A. R., Rezayat, S. M., Amini, M. A. \& Amani, A. Preparation and optimization of acetaminophen nanosuspension through nanoprecipitation using microfluidic devices: an artificial neural networks study. Pharm. Dev. Technol. 18, 609618 (2013). 
7. Wilson, W. I., Peng, Y. \& Augsburger, L. L. Generalization of a prototype intelligent hybrid system for hard gelatin capsule formulation development. AAPS PharmSciTech $\mathbf{6}$, E449--E457 (2005).

8. Firoozi, S., Amani, A., Derakhshan, M. A. \& Ghanbari, H. Artificial Neural Networks modeling of electrospun polyurethane nanofibers from chloroform/methanol solution. $J$. Nano Res. 41, 18-30 (2016).

9. Zhang, W. et al. Two modelling data analytical methods applied to optimise the preparation of norcantharidin chitosan nanoparticles. J. Exp. Nanosci. 5, 271-284 (2010).

10. Ibrić, S., Djuriš, J., Parojčić, J. \& Djurić, Z. Artificial neural networks in evaluation and optimization of modified release solid dosage forms. Pharmaceutics vol. 4 531-550 (2012).

11. Elsabahy, M., Loureiro, M. J. \& Foldvari, M. Handbook of Clinical Nanomedicine. Handbook of Clinical Nanomedicine (Jenny Stanford Publishing, 2016). doi:10.1201/b19910.

12. Mohamed, H. B., El-Shanawany, S. M., Hamad, M. A. \& Elsabahy, M. Niosomes: A Strategy toward Prevention of Clinically Significant Drug Incompatibilities. Sci. Rep. 7, 1-14 (2017).

13. Gharbavi, M., Amani, J., Kheiri-Manjili, H., Danafar, H. \& Sharafi, A. Niosome: A Promising Nanocarrier for Natural Drug Delivery through Blood-Brain Barrier. Advances in Pharmacological Sciences vol. 2018 (2018).

14. Chidambaram, S. B. et al. Mitochondria-targeted drug delivery in neurodegenerative diseases. in Delivery of Drugs: Volume 2: Expectations and Realities of Multifunctional Drug Delivery Systems 97-117 (Elsevier Inc., 2020). doi:10.1016/B978-0-12-8177761.00005-5.

15. Agatonovic-Kustrin, S. \& Morton, D. Data Mining in Drug Discovery and Design. in Artificial Neural Network for Drug Design, Delivery and Disposition 181-193 (Elsevier Inc., 2016). doi:10.1016/B978-0-12-801559-9.00009-0.

16. Shaheen, M., Shahbaz, M., Ur Rehman, Z. \& Guergachi, A. Data mining applications in hydrocarbon exploration. Artif. Intell. Rev. 35, 1-18 (2011).

17. Aksu, B. et al. Quality by design approach: Application of artificial intelligence techniques of tablets manufactured by direct compression. AAPS PharmSciTech 13, 11381146 (2012).

18. Pereira, A. K. V., Barbosa, R. de M., Fernandes, M. A. C., Finkler, L. \& Finkler, C. L. L. Comparative analyses of response surface methodology and artificial neural networks on incorporating tetracaine into liposomes. Brazilian J. Pharm. Sci. 56, 17808 (2020).

19. Kalantary, S., Jahani, A. \& Jahani, R. MLR and ANN Approaches for Prediction of Synthetic/Natural Nanofibers Diameter in the Environmental and Medical Applications. Sci. Rep. 10, 1-10 (2020). 
20. Shalaby, K. S. et al. Determination of factors controlling the particle size and entrapment efficiency of noscapine in PEG/PLA nanoparticles using artificial neural networks. Int. J. Nanomedicine 9, 4953-4964 (2014).

21. Youshia, J., Ali, M. E. \& Lamprecht, A. Artificial neural network based particle size prediction of polymeric nanoparticles. Eur. J. Pharm. Biopharm. 119, 333-342 (2017).

22. Knowles, J. Donepezil in Alzheimer's disease: An evidence-based review of its impact on clinical and economic outcomes. Core Evidence vol. 1 195-219 (2006).

23. Ruckmani, K. \& Sankar, V. Formulation and optimization of zidovudine niosomes. AAPS PharmSciTech 11, 1119-1127 (2010).

24. Moghddam, S. R. M., Ahad, A., Aqil, M., Imam, S. S. \& Sultana, Y. Formulation and optimization of niosomes for topical diacerein delivery using 3-factor, 3-level BoxBehnken design for the management of psoriasis. Mater. Sci. Eng. C 69, 789-797 (2016).

25. Qumbar, M. et al. Formulation and optimization of lacidipine loaded niosomal gel for transdermal delivery: In-vitro characterization and in-vivo activity. Biomed. Pharmacother. 93, 255-266 (2017).

26. Shirsand, S. B., Kanani, K. M., Keerthy, D., Nagendrakumar, D. \& Para, M. S. Formulation and evaluation of Ketoconazole niosomal gel drug delivery system. Int. J. Pharm. Investig. 2, 201 (2012).

27. Teaima, M. H., El Mohamady, A. M., El-Nabarawi, M. A. \& Mohamed, A. I. Formulation and evaluation of niosomal vesicles containing ondansetron HCL for trans-mucosal nasal drug delivery. Drug Dev. Ind. Pharm. 46, 751-761 (2020).

28. Ramadan, A. A., Eladawy, S. A., El-Enin, A. S. M. A. \& Hussein, Z. M. Development and investigation of timolol maleate niosomal formulations for the treatment of glaucoma. $J$. Pharm. Investig. 50, 59-70 (2020).

29. Rathi, J. C., Tamizharasi, S., Dubey, A. \& Rathi, V. Development and characterization of niosomal drug delivery of gliclazide. J. Young Pharm. 1, 205 (2009).

30. Jadon, P. S., Gajbhiye, V., Jadon, R. S., Gajbhiye, K. R. \& Ganesh, N. Enhanced oral bioavailability of griseofulvin via niosomes. AAPS PharmSciTech 10, 1186-1192 (2009).

31. Kamboj, S., Saini, V. \& Bala, S. Formulation and characterization of drug loaded nonionic surfactant vesicles (Niosomes) for oral bioavailability enhancement. Sci. World J. 2014, (2014).

32. Arafa, M. G. \& Ayoub, B. M. DOE Optimization of Nano-based Carrier of Pregabalin as Hydrogel: New Therapeutic $\{\backslash \&\}$ chemometric Approaches for Controlled Drug Delivery Systems. Sci. Rep. 7, 1-15 (2017).

33. Khalifa, A. L. Z. M. \& Abdul Rasool, B. K. Optimized Mucoadhesive Coated Niosomes as a Sustained Oral Delivery System of Famotidine. AAPS PharmSciTech 18, 3064-3075 (2017). 
34. Akbarzadeh, I. et al. Niosomal delivery of simvastatin to MDA-MB-231 cancer cells. Drug Dev. Ind. Pharm. 46, 1535-1549 (2020).

35. Bhattacharya, S. et al. Preparation and Evaluation of Diclofenac Sodium Niosomes Using Round Bottom Flask Method. Asian J. Pharm. 14, 188-194 (2020).

36. Samifar, S., Akki, R., Ramya, G. \& Vasu Naik, V. ACPI DEVELOPMENT AND CHARACTERIZATION OF CARBAMAZEPINE LOADED NONIONIC SURFACTANT VESICLES. Acta Chim. Pharm. Indica vol. 5 www.sadgurupublications.com (2015).

37. Sankhyan, A. \& Pawar, P. K. Metformin loaded non-ionic surfactant vesicles: Optimization of formulation, effect of process variables and characterization. DARU, J. Pharm. Sci. 21, 1-8 (2013).

38. Nasr, M., Mansour, S., Mortada, N. D. \& Elshamy, A. A. Vesicular aceclofenac systems: A comparative study between liposomes and niosomes. J. Microencapsul. 25, 499-512 (2008).

39. Das, M. K. \& Palei, N. N. Sorbitan ester niosomes for topical delivery of rofecoxib. Indian J. Exp. Biol. 49, 438-445 (2011).

40. Vogl, T. P., Mangis, J. K., Rigler, A. K., Zink, W. T. \& Alkon, D. L. Accelerating the convergence of the backpropagation method. Biol. Cybern. 59, 257-263 (1988).

41. Wayahdi, M. R., Zarlis, M. \& Putra, P. H. Initialization of the Nguyen-widrow and Kohonen Algorithm on the Backpropagation Method in the Classifying Process of Temperature Data in Medan. in Journal of Physics: Conference Series vol. 123512031 (Institute of Physics Publishing, 2019).

42. Marquardt, D. W. An Algorithm for Least-Squares Estimation of Nonlinear Parameters. $J$. Soc. Ind. Appl. Math. 11, 431-441 (1963).

43. Hagan, M. T. \& Menhaj, M. B. Training Feedforward Networks with the Marquardt Algorithm. IEEE Trans. Neural Networks 5, 989-993 (1994).

44. Zhang, J. \& Xu, C. Properties and numerical performance of quasi-Newton methods with modified quasi-Newton equations. J. Comput. Appl. Math. 137, 269-278 (2001).

45. Varshosaz, J., Pardakhty, A., Hajhashemi, V. I. \& Najafabadi, A. R. Development and Physical Characterization of Sorbitan Monoester Niosomes for Insulin Oral Delivery. Drug Deliv. J. Deliv. Target. Ther. Agents 10, 251-262 (2003). 
Table 1: Testing data set used to obtain the predicted data for the DNPZ Formulations

\begin{tabular}{|c|c|c|c|c|c|c|c|c|c|c|c|}
\hline $\begin{array}{c}\text { Formulati } \\
\text { on }^{\#}\end{array}$ & $\begin{array}{c}\text { Drug } \\
\text { /Lipi } \\
\text { d } \\
\text { Ratio }\end{array}$ & $\begin{array}{c}\text { Chol } \\
/ \\
\text { Spa } \\
\text { n 60 } \\
\text { Rati } \\
\text { o }\end{array}$ & $\begin{array}{c}\text { Drug } \\
\text { Mol. } \\
\text { wt. } \\
\text { (g/mo } \\
\text { l) }\end{array}$ & $\begin{array}{c}\text { Dru } \\
\text { g } \\
\text { Log } \\
\text { P }\end{array}$ & $\begin{array}{c}\text { Drug } \\
\text { Solubi } \\
\text { lity in } \\
\text { water } \\
\text { (mg/m } \\
\text { l) }\end{array}$ & $\begin{array}{c}\text { Dru } \\
\text { g } \\
\text { PK } \\
\text { A }\end{array}$ & $\begin{array}{c}\text { Spa } \\
\text { n60 } \\
\text { HL } \\
\text { B }\end{array}$ & $\begin{array}{c}\text { Hydr } \\
\text { ation } \\
\text { medi } \\
\text { um } \\
\text { amou } \\
\text { nt } \\
(\mathrm{ml})\end{array}$ & $\begin{array}{c}\text { Solve } \\
\text { nt } \\
\text { amou } \\
\text { nt } \\
(\mathrm{ml})\end{array}$ & $\begin{array}{c}\text { Tim } \\
\text { e of } \\
\text { Hyd } \\
\text { ratio } \\
\text { n } \\
(\mathrm{min} \\
\quad)\end{array}$ & $\begin{array}{c}\text { Temp } \\
\text { of } \\
\text { Hydr } \\
\text { ation } \\
\left({ }^{\circ} \mathrm{C}\right)\end{array}$ \\
\hline F1 & 0.10 & 0.20 & 416 & $\begin{array}{c}4.1 \\
4\end{array}$ & 0.0045 & $\begin{array}{l}17 . \\
02\end{array}$ & 4.7 & 10 & 10.00 & $\begin{array}{c}60.0 \\
0\end{array}$ & 55.00 \\
\hline $\mathrm{F} 2$ & 0.10 & 0.33 & 416 & $\begin{array}{c}4.1 \\
4\end{array}$ & 0.0045 & $\begin{array}{l}17 . \\
02\end{array}$ & 4.7 & 10 & 10.00 & $\begin{array}{c}60.0 \\
0\end{array}$ & 55.00 \\
\hline F3 & 0.10 & 1.00 & 416 & $\begin{array}{c}4.1 \\
4\end{array}$ & 0.0045 & $\begin{array}{l}17 . \\
02\end{array}$ & 4.7 & 10 & 10.00 & $\begin{array}{c}60.0 \\
0\end{array}$ & 55.00 \\
\hline F4 & 0.14 & 0.20 & 416 & $\begin{array}{c}4.1 \\
4\end{array}$ & 0.0045 & $\begin{array}{l}17 . \\
02\end{array}$ & 4.7 & 10 & 10.00 & $\begin{array}{c}60.0 \\
0\end{array}$ & 55.00 \\
\hline F5 & 0.14 & 0.33 & 416 & $\begin{array}{c}4.1 \\
4\end{array}$ & 0.0045 & $\begin{array}{l}17 . \\
02\end{array}$ & 4.7 & 10 & 10.00 & $\begin{array}{c}60.0 \\
0\end{array}$ & 55.00 \\
\hline F6 & 0.14 & 1.00 & 416 & $\begin{array}{c}4.1 \\
4\end{array}$ & 0.0045 & $\begin{array}{l}17 . \\
02\end{array}$ & 4.7 & 10 & 10.00 & $\begin{array}{c}60.0 \\
0\end{array}$ & 55.00 \\
\hline F7 & 0.25 & 0.20 & 416 & $\begin{array}{c}4.1 \\
4\end{array}$ & 0.0045 & $\begin{array}{l}17 . \\
02\end{array}$ & 4.7 & 10 & 10.00 & $\begin{array}{c}60.0 \\
0\end{array}$ & 55.00 \\
\hline F8 & 0.25 & 0.33 & 416 & $\begin{array}{c}4.1 \\
4\end{array}$ & 0.0045 & $\begin{array}{l}17 . \\
02\end{array}$ & 4.7 & 10 & 10.00 & $\begin{array}{c}60.0 \\
0\end{array}$ & 55.00 \\
\hline F9 & 0.25 & 1.00 & 416 & $\begin{array}{c}4.1 \\
4\end{array}$ & 0.0045 & $\begin{array}{l}17 . \\
02\end{array}$ & 4.7 & 10 & 10.00 & $\begin{array}{c}60.0 \\
0\end{array}$ & 55.00 \\
\hline
\end{tabular}

\footnotetext{
\#Nine formulations of DNPZ-loaded niosomes were designed using 3x3 factorial design using different drug/lipid ratio and Chol/Span60 ratios. Other parameters were used either as reported in a literature (for drug molecular weight, $\log$ P, solubility in water, PKA and Span60 HLB) rent surfactants and different surfactant: CHOL molar ratios or kept constant (solvent amount, hydration medium amount, time, and temperature of hydration). DNPZ was taken as $10 \mathrm{mg}$ per batch.
} 
Table 2: EE\% Prediction results for different Algorithms

\begin{tabular}{|l|c|c|c|c|c|c|}
\hline Algorithm & $\begin{array}{l}\text { Training } \\
\text { Time (s) }\end{array}$ & $\begin{array}{l}\text { Test } \\
\text { MSE }\end{array}$ & $\begin{array}{l}\text { Validation } \\
\text { MSE }\end{array}$ & $\begin{array}{l}\text { Train } \\
\text { MSE }\end{array}$ & $\begin{array}{l}\text { Over } \\
\text { MSE }\end{array}$ & $\begin{array}{l}\text { Prediction } \\
\text { Accuracy }\end{array}$ \\
\hline $\begin{array}{l}\text { Levenberg- } \\
\text { Marquardt }\end{array}$ & 3 & 16.65 & 22.31 & 28.45 & 25.77 & 0.94 \\
\hline $\begin{array}{l}\text { Bayesian } \\
\text { Regularization }\end{array}$ & 4 & 28.84 & NaN & 24.89 & 25.48 & 89.90 \\
\hline $\begin{array}{l}\text { BFGS Quasi- } \\
\text { Newton }\end{array}$ & 3 & 73.97 & 96.28 & 89.39 & 88.11 & 91.96 \\
\hline $\begin{array}{l}\text { Resilient } \\
\text { Backpropagation }\end{array}$ & 4.3 & 105.28 & 111.86 & 88.27 & 94.35 & 91.95 \\
\hline $\begin{array}{l}\text { Scaled Conjugate } \\
\text { Gradient }\end{array}$ & 5.2 & 68.34 & 76.36 & 74.02 & 73.52 & 90.82 \\
\hline $\begin{array}{l}\text { Conjugate } \\
\text { Gradient } \\
\begin{array}{l}\text { Powell/Beale } \\
\text { Restarts }\end{array}\end{array}$ & 4 & 72.53 & 64.34 & 62.83 & 64.51 & 87.79 \\
\hline
\end{tabular}


Table 3: Particle Size Prediction for different Algorithms

\begin{tabular}{|c|l|l|l|l|l|l|}
\hline Algorithm & $\begin{array}{l}\text { Training } \\
\text { Time (s) }\end{array}$ & Test MSE & $\begin{array}{l}\text { Validation } \\
\text { MSE }\end{array}$ & Train MSE & Over MSE & $\begin{array}{l}\text { Prediction } \\
\text { Accuracy } \\
(\%)\end{array}$ \\
\hline $\begin{array}{c}\text { Levenberg- } \\
\text { Marquardt }\end{array}$ & 3 & 72.53 & 64.3376 & 62.83 & 64.51 & 91.79 \\
\hline $\begin{array}{c}\text { Bayesian } \\
\text { Regularization }\end{array}$ & 4 & 506.29 & NaN & 508.53 & 508.19 & 85.00 \\
\hline $\begin{array}{c}\text { BFGS Quasi- } \\
\text { Newton }\end{array}$ & 3 & $5.22 \mathrm{e}+06$ & $5.17 \mathrm{e}+06$ & $5.54 \mathrm{e}+06$ & $5.08 \mathrm{e}+06$ & 0.0001 \\
\hline $\begin{array}{c}\text { Resilient } \\
\text { Backpropagation }\end{array}$ & 4.3 & $6.51 \mathrm{e}+04$ & $6.27 \mathrm{e}+04$ & $5.99 \mathrm{e}+04$ & $6.11 \mathrm{e}+04$ & 0.01 \\
\hline $\begin{array}{c}\text { Scaled Conjugate } \\
\text { Gradient }\end{array}$ & 5.2 & $8.46 \mathrm{e}+03$ & $8.57 \mathrm{e}+03$ & $8.19 \mathrm{e}+03$ & $8.23 \mathrm{e}+03$ & 0.10 \\
\hline $\begin{array}{c}\text { Conjugate } \\
\text { Gradient with } \\
\text { Powell/Beale } \\
\text { Restarts }\end{array}$ & 4 & $6.79 \mathrm{e}+03$ & $6.86 \mathrm{e}+03$ & $6.53 \mathrm{e}+03$ & $6.62 \mathrm{e}+03$ & 0.10 \\
\hline
\end{tabular}


Table 4: Predicted and Experimental values for the DNPZ noisome formulations along with the \% prediction error and \%accuracy

\begin{tabular}{|c|c|c|c|c|c|c|c|c|}
\hline $\begin{array}{c}\text { For } \\
\text { mula } \\
\text { tion }\end{array}$ & $\begin{array}{l}\text { EE } \\
\% \\
\text { Pre } \\
\text { dic } \\
\text { ted }\end{array}$ & $\begin{array}{c}\text { EE\% } \\
\text { Experimental } \\
(\text { Mean } \pm \text { SD) }\end{array}$ & $\begin{array}{c}\text { EE } \\
\% \\
\text { Pre } \\
\text { dicti } \\
\text { on } \\
\text { Err } \\
\text { or } \\
(\%)\end{array}$ & $\begin{array}{c}\text { EE } \\
\% \\
\text { Pre } \\
\text { dicti } \\
\text { on } \\
\text { Acc } \\
\text { ura } \\
\text { cy } \\
(\%)\end{array}$ & $\begin{array}{c}\text { Par } \\
\text { ticle } \\
\text { Size } \\
\text { Pre } \\
\text { dict } \\
\text { ed }\end{array}$ & $\begin{array}{c}\text { Particle Size } \\
\text { Experimental } \\
\text { (Mean } \pm \text { SD) }\end{array}$ & $\begin{array}{l}\text { Particle } \\
\text { Size } \\
\text { prediction } \\
\text { Error (\%) }\end{array}$ & $\begin{array}{c}\text { Particle } \\
\text { Size } \\
\text { Predictio } \\
\text { n } \\
\text { Accurac } \\
\text { y }(\%)\end{array}$ \\
\hline F1 & $\begin{array}{r}85 . \\
23\end{array}$ & $88.71 \pm 0.13$ & 3.92 & $\begin{array}{r}96.0 \\
8\end{array}$ & $\begin{array}{r}138 \\
3.6\end{array}$ & $859.9 \pm 47.5$ & 60.91 & 39.09 \\
\hline $\mathrm{F} 2$ & $\begin{array}{c}86 . \\
96\end{array}$ & $90.75 \pm 1.09$ & 4.17 & $\begin{array}{r}95.8 \\
3\end{array}$ & $\begin{array}{r}127 \\
4.9\end{array}$ & $966.9 \pm 52.4$ & 31.85 & 68.15 \\
\hline $\mathrm{F} 3$ & $\begin{array}{r}80 . \\
63\end{array}$ & $79.08 \pm 0.50$ & 1.97 & $\begin{array}{r}98.0 \\
3\end{array}$ & $\begin{array}{r}112 \\
9.1\end{array}$ & $1361.1 \pm 67.6$ & 17.04 & 82.96 \\
\hline F4 & $\begin{array}{r}87 . \\
79\end{array}$ & $82.15 \pm 2.46$ & 6.86 & $\begin{array}{r}93.1 \\
4\end{array}$ & $\begin{array}{r}217 \\
7\end{array}$ & $2507.3 \pm 79.9$ & 13.17 & 86.83 \\
\hline F5 & $\begin{array}{r}89 . \\
81\end{array}$ & $91.63 \pm 0.83$ & 1.98 & $\begin{array}{r}98.0 \\
2\end{array}$ & $\begin{array}{r}171 \\
5.5 \\
\end{array}$ & $1864.4 \pm 105.4$ & 7.99 & 92.01 \\
\hline F6 & $\begin{array}{c}85 . \\
46\end{array}$ & $84.91 \pm 2.80$ & 0.65 & $\begin{array}{r}99.3 \\
5\end{array}$ & $\begin{array}{r}723 . \\
2\end{array}$ & $542.9 \pm 38.8$ & 33.22 & 66.78 \\
\hline F7 & $\begin{array}{r}93 . \\
35\end{array}$ & $93.93 \pm 0.64$ & 0.62 & $\begin{array}{r}99.3 \\
8\end{array}$ & $\begin{array}{r}242 \\
9.3 \\
\end{array}$ & $2361.3 \pm 119.6$ & 2.88 & 97.12 \\
\hline F8 & $\begin{array}{r}95 . \\
92\end{array}$ & $98.00 \pm 0.49$ & 2.12 & $\begin{array}{r}97.8 \\
8\end{array}$ & $\begin{array}{r}148 \\
7.3\end{array}$ & $1408.8 \pm 116.4$ & 5.57 & 94.43 \\
\hline F9 & $\begin{array}{r}95 . \\
91\end{array}$ & $94.89 \pm 0.53$ & 1.08 & $\begin{array}{r}98.9 \\
2\end{array}$ & $\begin{array}{r}410 . \\
1\end{array}$ & $475.5 \pm 43.4$ & 13.75 & 86.25 \\
\hline
\end{tabular}


Table 5: The analysis of variance table for \% Entrapment Efficiency as the response (Y1) and particle size of DNPZ niosomes as the response Y2.

\begin{tabular}{|c|c|c|c|c|c|c|c|c|c|c|c|c|c|}
\hline \multirow{2}{*}{\multicolumn{7}{|c|}{$\begin{array}{l}\text { Response Y1: Entrapment Efficiency } \\
\text { ANOVA for Response Surface Quadratic } \\
\text { model }\end{array}$}} & \multirow{2}{*}{\multicolumn{7}{|c|}{$\begin{array}{l}\text { Response Y2: Vesicle Size } \\
\text { ANOVA for Response Surface 2FI model }\end{array}$}} \\
\hline & & & & & & & & & & & & & \\
\hline source & $\begin{array}{l}\text { Su } \\
\mathrm{m} \\
\text { of } \\
\text { squ } \\
\text { ares }\end{array}$ & $\begin{array}{l}\text { d } \\
\text { f }\end{array}$ & $\begin{array}{l}\text { Me } \\
\text { an } \\
\text { squ } \\
\text { are }\end{array}$ & $\begin{array}{l}\text { F- } \\
\text { val } \\
\text { ue }\end{array}$ & $\begin{array}{l}\text { P- } \\
\text { val } \\
\text { ue }\end{array}$ & & Source & $\begin{array}{l}\text { Sum } \\
\text { of } \\
\text { Squa } \\
\text { res }\end{array}$ & $\begin{array}{l}\text { d } \\
\mathbf{f}\end{array}$ & $\begin{array}{l}\text { Mea } \\
\text { n } \\
\text { Squa } \\
\text { re }\end{array}$ & $\begin{array}{l}\text { F- } \\
\text { val } \\
\text { ue }\end{array}$ & $\begin{array}{l}\text { p- } \\
\text { val } \\
\text { ue }\end{array}$ & \\
\hline Model & $\begin{array}{l}287 . \\
07\end{array}$ & 5 & $\begin{array}{l}57 . \\
41\end{array}$ & $\begin{array}{l}7.1 \\
7\end{array}$ & $\begin{array}{l}0.0 \\
678\end{array}$ & $\begin{array}{l}\text { not } \\
\text { signif } \\
\text { icant }\end{array}$ & Model & $\begin{array}{l}3.48 \\
E+06\end{array}$ & 3 & $\begin{array}{l}1.16 \\
\mathrm{E}+06\end{array}$ & $\begin{array}{l}6.1 \\
1\end{array}$ & $\begin{array}{l}0.0 \\
398\end{array}$ & $\begin{array}{l}\text { signif } \\
\text { icant }\end{array}$ \\
\hline $\begin{array}{l}\text { A- } \\
\text { Lipid/ } \\
\text { Drug } \\
\text { ratio }\end{array}$ & $\begin{array}{l}133 . \\
29\end{array}$ & 1 & $\begin{array}{l}133 \\
.29\end{array}$ & $\begin{array}{l}16 . \\
65\end{array}$ & $\begin{array}{l}0.0 \\
266\end{array}$ & & $\begin{array}{l}\text { A- } \\
\text { Lipid/ } \\
\text { Drug } \\
\text { ratio }\end{array}$ & $\begin{array}{l}1.87 \\
E+05\end{array}$ & 1 & $\begin{array}{l}1.87 \\
\mathrm{E}+05\end{array}$ & $\begin{array}{l}0.9 \\
826\end{array}$ & $\begin{array}{l}0.3 \\
671\end{array}$ & \\
\hline $\begin{array}{l}\text { B- } \\
\text { span60/ } \\
\text { CHOL }\end{array}$ & 5.82 & 1 & $\begin{array}{l}5.8 \\
2\end{array}$ & $\begin{array}{l}0.7 \\
273\end{array}$ & $\begin{array}{l}0.4 \\
564\end{array}$ & & $\begin{array}{l}\text { B- } \\
\text { span60/ } \\
\text { CHOL }\end{array}$ & $\begin{array}{l}1.87 \\
E+06\end{array}$ & 1 & $\begin{array}{l}1.87 \\
\mathrm{E}+06\end{array}$ & $\begin{array}{l}9.8 \\
5\end{array}$ & $\begin{array}{l}0.0 \\
257\end{array}$ & \\
\hline $\mathrm{AB}$ & $\begin{array}{l}28.0 \\
4\end{array}$ & 1 & $\begin{array}{l}28 . \\
04\end{array}$ & 3.5 & $\begin{array}{l}0.1 \\
58\end{array}$ & & $\mathrm{AB}$ & $\begin{array}{l}1.43 \\
E+06\end{array}$ & 1 & $\begin{array}{l}1.43 \\
E+06\end{array}$ & $\begin{array}{l}7.5 \\
1\end{array}$ & $\begin{array}{l}0.0 \\
408\end{array}$ & \\
\hline $\mathrm{A}^{2}$ & $\begin{array}{l}43.4 \\
9\end{array}$ & 1 & $\begin{array}{l}43 . \\
49\end{array}$ & $\begin{array}{l}5.4 \\
3\end{array}$ & $\begin{array}{l}0.1 \\
021\end{array}$ & & $\begin{array}{l}\text { Residua } \\
1\end{array}$ & $\begin{array}{l}9.49 \\
E+05\end{array}$ & 5 & $\begin{array}{l}1.90 \\
E+05\end{array}$ & & & \\
\hline $\mathrm{B}^{2}$ & $\begin{array}{l}76.4 \\
3\end{array}$ & 1 & $\begin{array}{l}76 . \\
43\end{array}$ & $\begin{array}{l}9.5 \\
5\end{array}$ & $\begin{array}{l}0.0 \\
537\end{array}$ & & $\begin{array}{l}\text { Cor } \\
\text { Total }\end{array}$ & $\begin{array}{l}4.43 \\
E+06\end{array}$ & 8 & & & & \\
\hline $\begin{array}{l}\text { Residua } \\
1\end{array}$ & $\begin{array}{l}24.0 \\
1\end{array}$ & 3 & 8 & & & & & & & & & & \\
\hline $\begin{array}{l}\text { Cor } \\
\text { Total }\end{array}$ & $\begin{array}{l}311 . \\
08\end{array}$ & 8 & & & & & & & & & & & \\
\hline
\end{tabular}


Table 6: Comparison between experimental data and predictive models generated by RSM and ANN for DNPZ Niosome Vesicle size.

\begin{tabular}{|c|c|c|c|c|}
\hline $\begin{array}{l}\text { Particle } \\
\text { size } \\
\text { Observed } \\
(\mathrm{nm})\end{array}$ & \begin{tabular}{|l} 
ANN \\
Particle \\
size \\
predicted
\end{tabular} & $\begin{array}{l}\text { \% } \\
\text { Error }\end{array}$ & $\begin{array}{l}\text { RSM } \\
\text { Particle } \\
\text { size } \\
\text { predicted }\end{array}$ & $\begin{array}{l}\% \\
\text { Error }\end{array}$ \\
\hline 859.87 & 1383.61 & 0.61 & 1157.14 & 0.35 \\
\hline 966.93 & 1274.89 & 0.32 & 1195.73 & 0.24 \\
\hline 1361.10 & 1129.09 & 0.17 & 1234.33 & 0.09 \\
\hline 2507.33 & 2176.98 & 0.13 & 1930.20 & 0.23 \\
\hline 1864.43 & 1715.52 & 0.08 & 1372.02 & 0.26 \\
\hline 542.90 & 723.25 & 0.33 & 813.84 & 0.50 \\
\hline 2361.33 & 2429.29 & 0.03 & 2703.26 & 0.14 \\
\hline 1408.83 & 1487.30 & 0.06 & 1548.31 & 0.10 \\
\hline 475.47 & 4410.09 & 0.14 & 393.36 & 0.17 \\
\hline Parameter & & ANN & & $\begin{array}{l}\text { RSM } \\
\end{array}$ \\
\hline MSE & & 66873 & & 105429 \\
\hline RMSE & & 258.598 & & 324.698 \\
\hline $\mathrm{R}^{2}$ & & 0.994 & & 0.992 \\
\hline
\end{tabular}




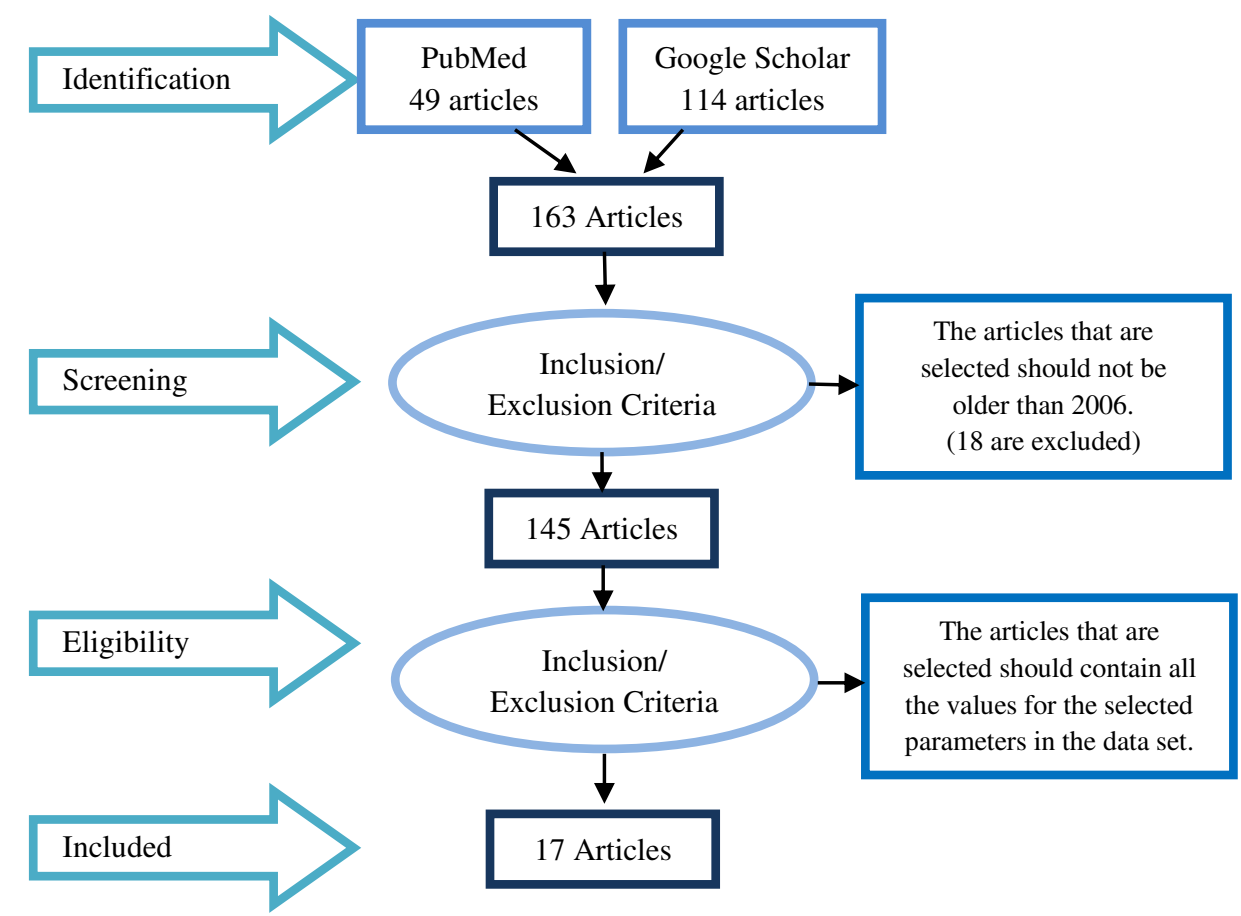

Figure 1: PRISMA (Preferred Reporting Items for Systematic Reviews and Meta-Analyses) Flow Diagram used to collect the network dataset. 


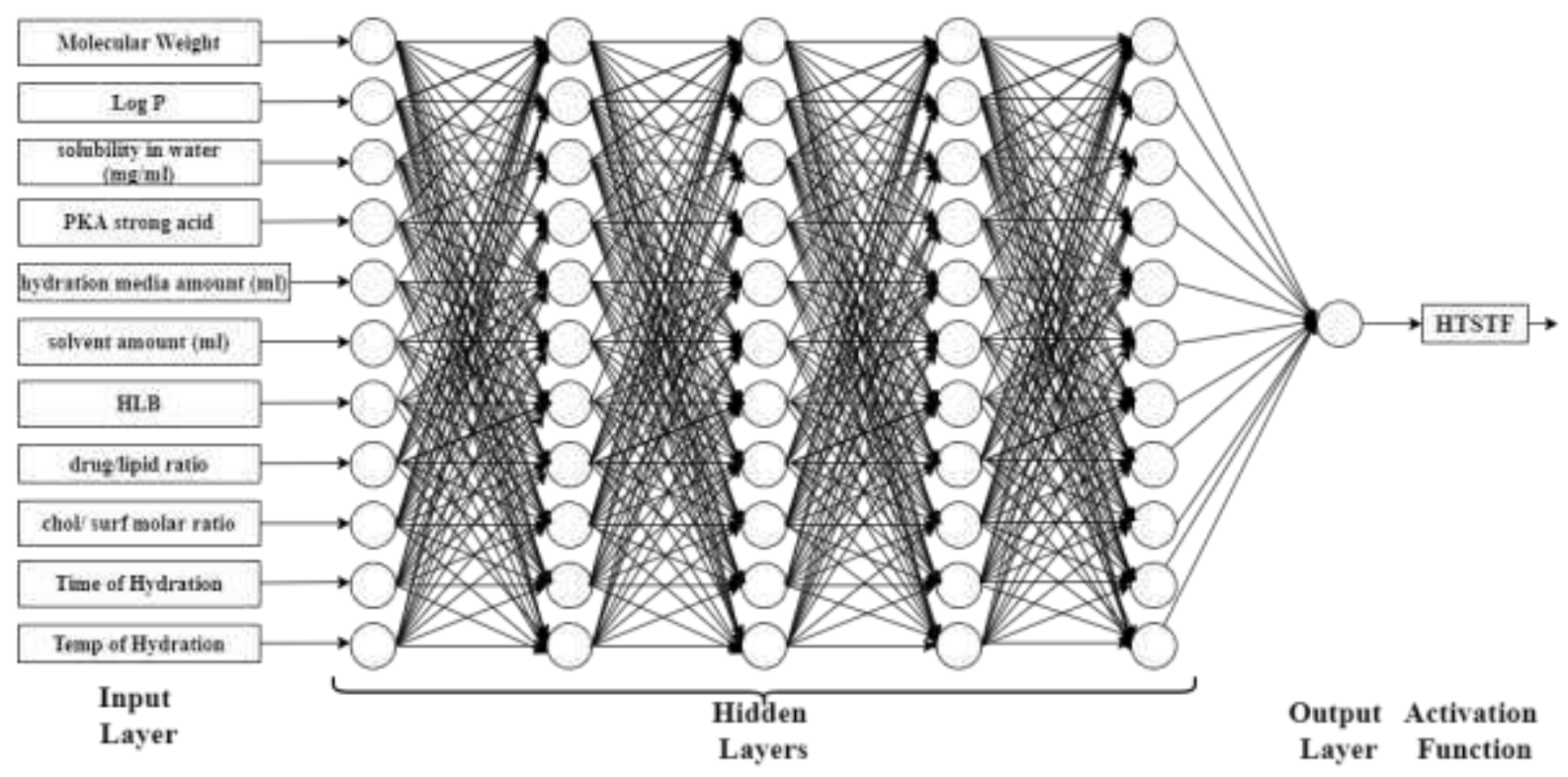

Figure 2: Network work architecture 


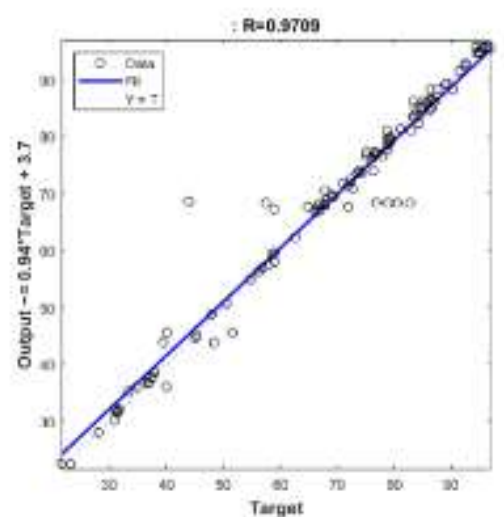

Levenberg-Marquardt

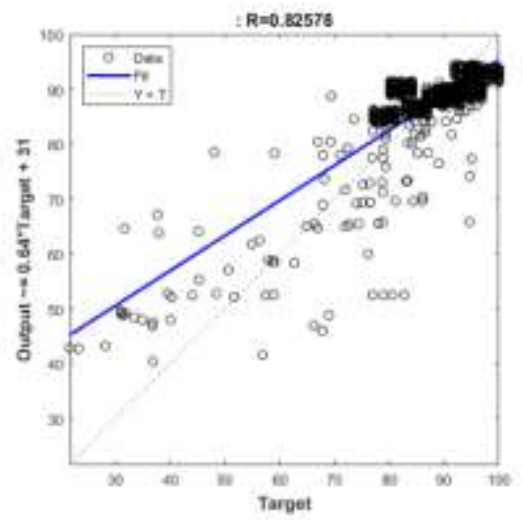

BFGS Quasi-Newton

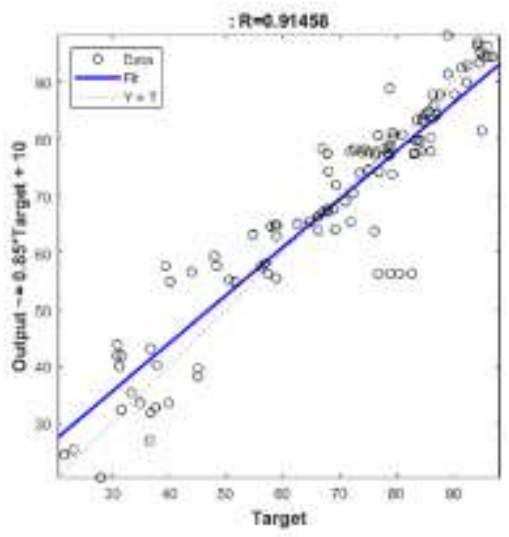

Scaled Conjugate Gradient

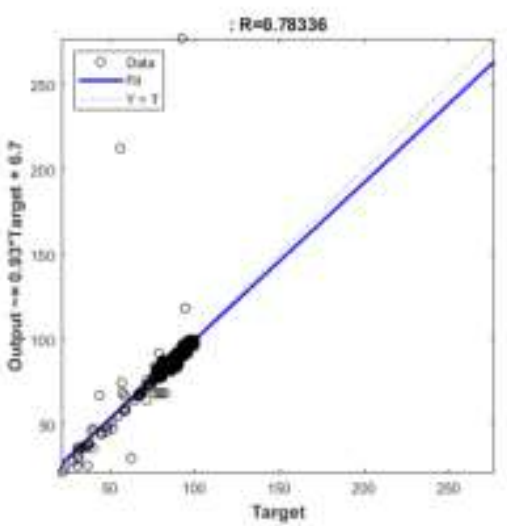

Bayesian Regularization

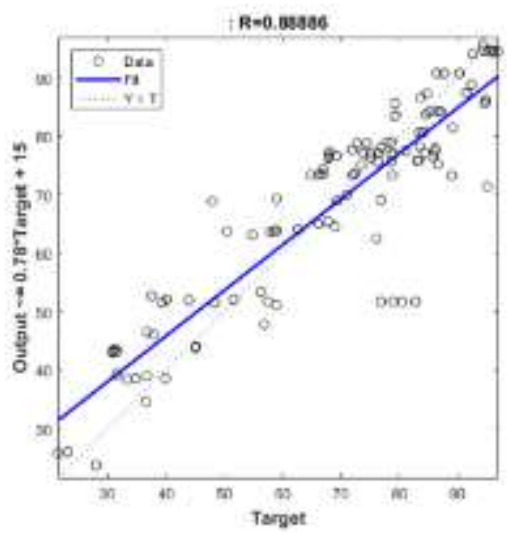

Resilient Backpropagation

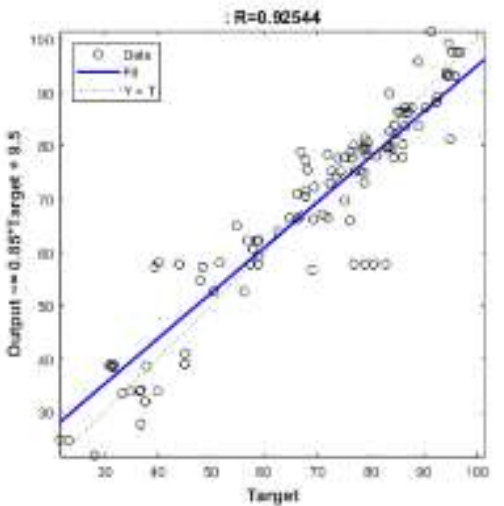

Conjugate Gradient with Powell/Beale Restarts

Figure 3: \% EE Regression plots for different backpropagation algorithms 



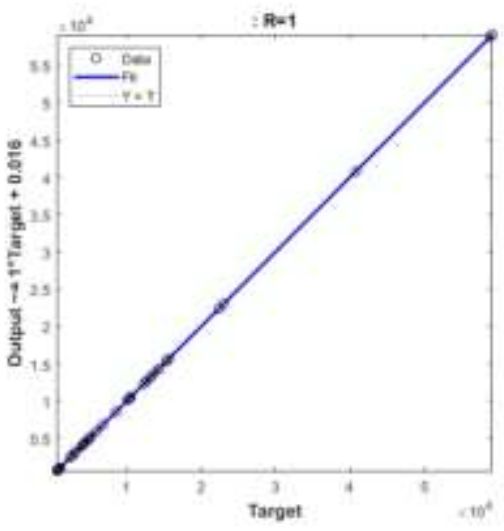

Levenberg-Marquardt

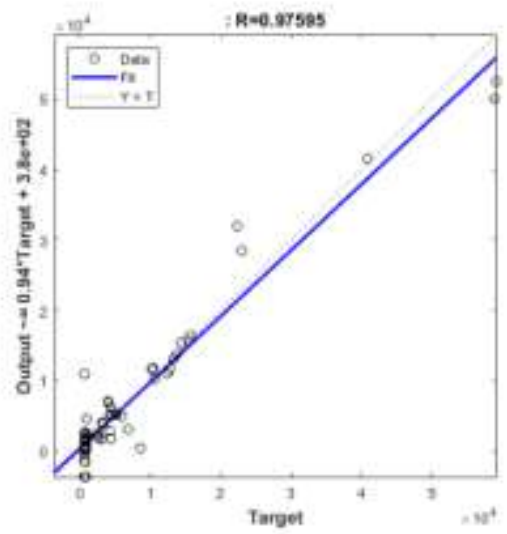

BFGS Quasi-Newton

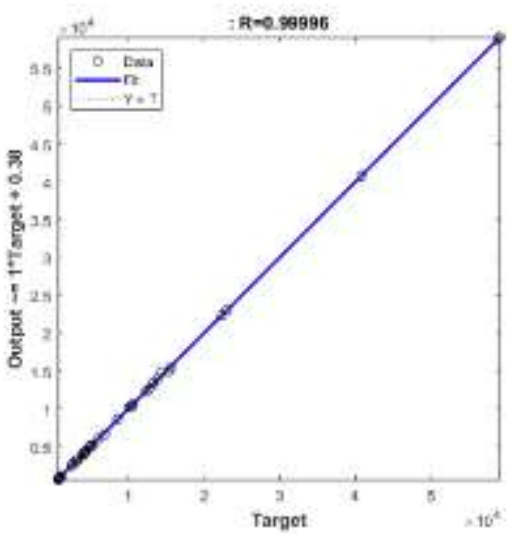

Scaled Conjugate Gradient

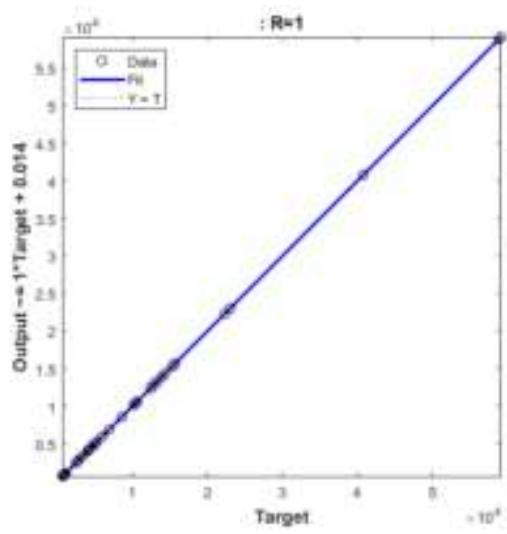

Bayesian Regularization

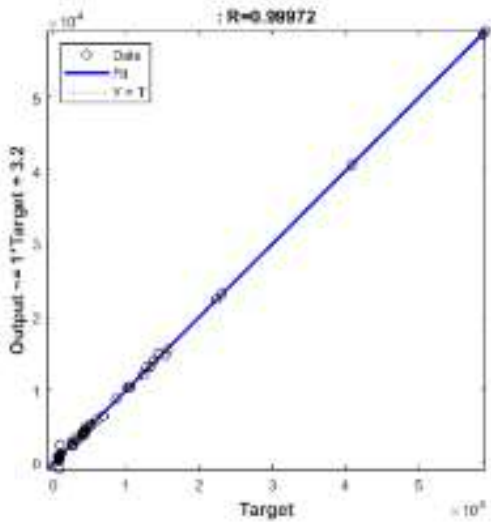

Resilient Backpropagation

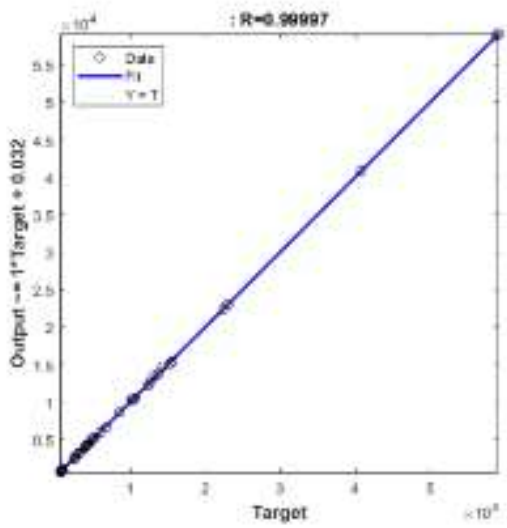

Conjugate Gradient with Powell/Beale Restarts

Figure 4: Particle size Regression plots for different backpropagation algorithms 


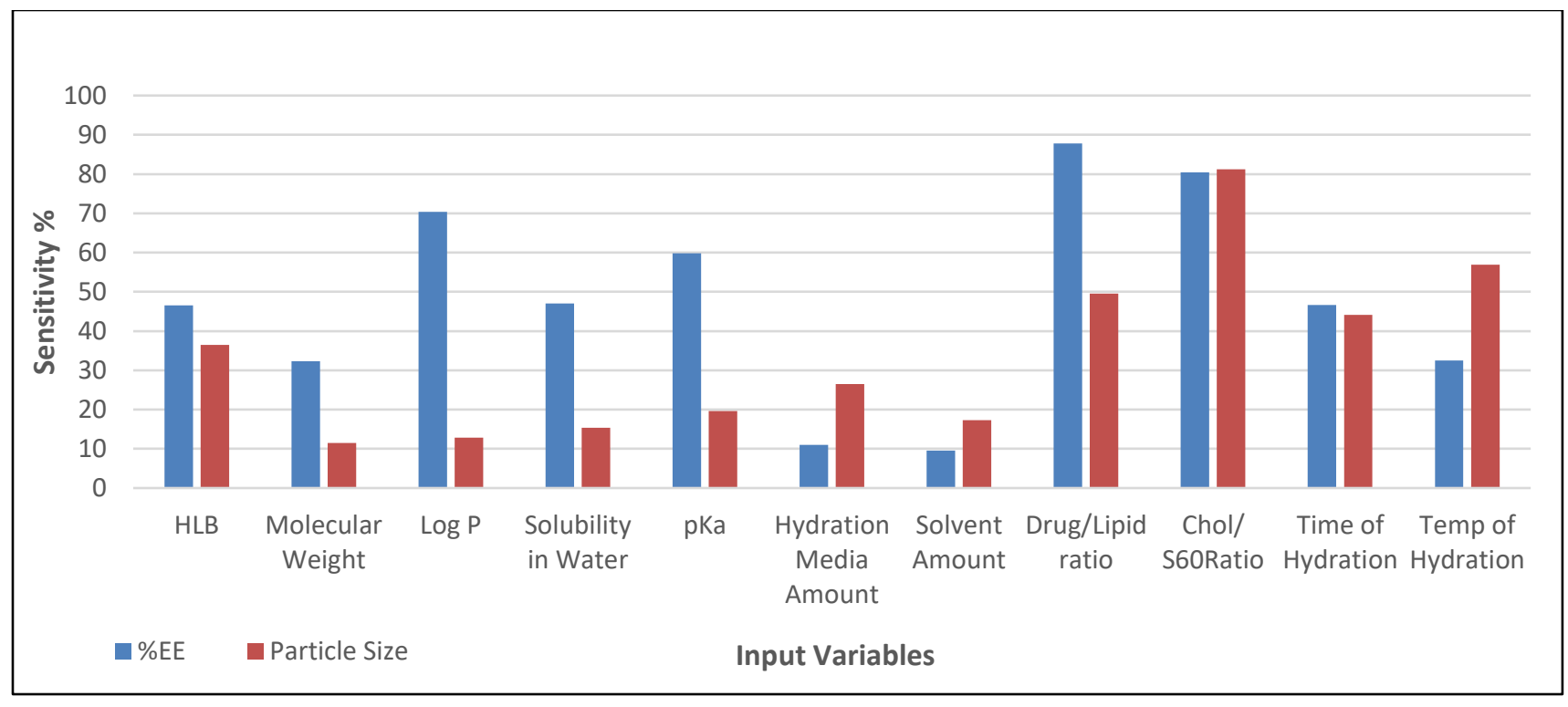

Figure 5: Results of the sensitivity analysis of ANN 


\section{Supplementary data: (Appendix A)}

Input variables for the experiments collected from the literature (training, validation, and test data sets)

\begin{tabular}{|c|c|c|c|c|c|c|c|c|c|c|c|c|}
\hline $\begin{array}{c}\text { Molecul } \\
\text { ar } \\
\text { Weight }\end{array}$ & $\begin{array}{c}\mathbf{L} \\
\mathbf{o g} \\
\mathbf{P}\end{array}$ & $\begin{array}{c}\text { Solubility in } \\
\text { water } \\
(\mathrm{mg} / \mathrm{ml})\end{array}$ & $\begin{array}{c}\text { PKA } \\
\text { strong } \\
\text { acid }\end{array}$ & $\begin{array}{c}\text { Hydration } \\
\text { media } \\
\text { amount }(\mathrm{ml})\end{array}$ & $\begin{array}{l}\text { Solvent } \\
\text { amount } \\
\quad(\mathrm{ml})\end{array}$ & $\begin{array}{l}\mathbf{H} \\
\mathbf{L} \\
\mathbf{B}\end{array}$ & $\begin{array}{c}\text { Drug/L } \\
\text { ipid } \\
\text { ratio }\end{array}$ & $\begin{array}{c}\text { Chol/ } \\
\text { S60Ra } \\
\text { tio }\end{array}$ & $\begin{array}{c}\text { Time of } \\
\text { Hydrati } \\
\text { on }\end{array}$ & $\begin{array}{c}\text { Temp of } \\
\text { Hydrati } \\
\text { on } \\
\left({ }^{\circ} \mathrm{C}\right)\end{array}$ & $\begin{array}{c}\% \\
\mathrm{E} \\
\mathrm{E} \\
( \\
\% \\
)\end{array}$ & $\begin{array}{c}\text { Particle } \\
\text { size } \\
(\mathbf{n m})\end{array}$ \\
\hline 267.24 & $\begin{array}{r}0 . \\
05\end{array}$ & 15.00 & 9.96 & 6.00 & 10.00 & $\begin{array}{r}4 . \\
7 \\
0 \\
\end{array}$ & 1.64 & 0.22 & 45.00 & 60.00 & $\begin{array}{r}86 \\
.6 \\
0\end{array}$ & 2660.00 \\
\hline 267.24 & $\begin{array}{r}0 . \\
05\end{array}$ & 15.00 & 9.96 & 6.00 & 10.00 & $\begin{array}{r}4 . \\
7 \\
0 \\
\end{array}$ & 1.55 & 0.22 & 45.00 & 60.00 & $\begin{array}{r}85 \\
.7 \\
0 \\
\end{array}$ & 2480.00 \\
\hline 368.30 & $\begin{array}{c}3 . \\
13\end{array}$ & 0.010 & 3.37 & 10.00 & 10.00 & $\begin{array}{r}4 . \\
7 \\
0 \\
\end{array}$ & 0.01 & 0.07 & 45.00 & 60.00 & $\begin{array}{r}83 \\
.3 \\
6 \\
\end{array}$ & 474.00 \\
\hline 368.30 & $\begin{array}{r}3 \\
13\end{array}$ & 0.010 & 3.37 & 10.00 & 10.00 & $\begin{array}{r}4 . \\
7 \\
0 \\
\end{array}$ & 0.01 & 0.12 & 45.00 & 60.00 & $\begin{array}{r}83 \\
.0 \\
2 \\
\end{array}$ & 477.80 \\
\hline 368.30 & $\begin{array}{r}3 \\
13\end{array}$ & 0.010 & 3.37 & 10.00 & 10.00 & $\begin{array}{r}4 . \\
7 \\
0 \\
\end{array}$ & 0.01 & 0.21 & 75.00 & 60.00 & $\begin{array}{r}72 \\
.6 \\
9 \\
\end{array}$ & 306.10 \\
\hline 368.30 & $\begin{array}{r}3 . \\
13\end{array}$ & 0.010 & 3.37 & 10.00 & 10.00 & $\begin{array}{r}4 . \\
7 \\
0 \\
\end{array}$ & 0.01 & 0.16 & 75.00 & 60.00 & $\begin{array}{r}74 \\
.3 \\
8 \\
\end{array}$ & 420.80 \\
\hline 368.30 & $\begin{array}{r}3 . \\
13\end{array}$ & 0.010 & 3.37 & 10.00 & 10.00 & $\begin{array}{r}4 . \\
7 \\
0 \\
\end{array}$ & 0.01 & 0.06 & 60.00 & 60.00 & $\begin{array}{r}86 \\
.0 \\
4\end{array}$ & 316.00 \\
\hline 368.30 & $\begin{array}{r}3 . \\
13\end{array}$ & 0.010 & 3.37 & 10.00 & 10.00 & $\begin{array}{r}4 . \\
7 \\
0 \\
\end{array}$ & 0.01 & 0.14 & 60.00 & 60.00 & $\begin{array}{r}76 \\
.4 \\
7 \\
\end{array}$ & 481.00 \\
\hline 368.30 & $\begin{array}{r}3 . \\
13\end{array}$ & 0.010 & 3.37 & 10.00 & 10.00 & $\begin{array}{r}4 . \\
7 \\
0 \\
\end{array}$ & 0.01 & 0.24 & 60.00 & 60.00 & $\begin{array}{r}67 \\
.8 \\
4 \\
\end{array}$ & 650.80 \\
\hline 368.30 & $\begin{array}{r}3 \\
13\end{array}$ & 0.010 & 3.37 & 10.00 & 10.00 & $\begin{array}{r}4 . \\
7 \\
0 \\
\end{array}$ & 0.01 & 0.14 & 60.00 & 60.00 & $\begin{array}{r}76 \\
.5 \\
0 \\
\end{array}$ & 482.00 \\
\hline 368.30 & $\begin{array}{r}3 . \\
13\end{array}$ & 0.010 & 3.37 & 10.00 & 10.00 & $\begin{array}{r}4 . \\
7 \\
0 \\
\end{array}$ & 0.01 & 0.14 & 60.00 & 60.00 & $\begin{array}{r}75 \\
.1 \\
1\end{array}$ & 480.00 \\
\hline 368.30 & $\begin{array}{r}3 . \\
13\end{array}$ & 0.010 & 3.37 & 10.00 & 10.00 & $\begin{array}{r}4 . \\
7 \\
0 \\
\end{array}$ & 0.01 & 0.19 & 60.00 & 60.00 & $\begin{array}{r}73 \\
.9 \\
1 \\
\end{array}$ & 500.40 \\
\hline 368.30 & $\begin{array}{r}3 . \\
13\end{array}$ & 0.010 & 3.37 & 10.00 & 10.00 & $\begin{array}{r}4 . \\
7 \\
0 \\
\end{array}$ & 0.01 & 0.08 & 60.00 & 60.00 & $\begin{array}{r}84 \\
.3 \\
4 \\
\end{array}$ & 459.30 \\
\hline 368.30 & $\begin{array}{r}3 . \\
13\end{array}$ & 0.010 & 3.37 & 10.00 & 10.00 & $\begin{array}{r}4 . \\
7 \\
0 \\
\end{array}$ & 0.01 & 0.12 & 75.00 & 60.00 & $\begin{array}{r}77 \\
.9 \\
5 \\
\end{array}$ & 450.90 \\
\hline 368.30 & $\begin{array}{r}3 . \\
13\end{array}$ & 0.010 & 3.37 & 10.00 & 10.00 & $\begin{array}{r}4 . \\
7 \\
0 \\
\end{array}$ & 0.01 & 0.21 & 45.00 & 60.00 & $\begin{array}{r}76 \\
.3 \\
1 \\
\end{array}$ & 647.30 \\
\hline 368.30 & $\begin{array}{r}3 \\
13\end{array}$ & 0.010 & 3.37 & 10.00 & 10.00 & $\begin{array}{r}4 . \\
7 \\
0 \\
\end{array}$ & 0.01 & 0.07 & 75.00 & 60.00 & $\begin{array}{r}78 \\
.7 \\
3 \\
\end{array}$ & 360.80 \\
\hline 455.54 & $\begin{array}{r}4 . \\
19\end{array}$ & 0.002 & 19.47 & 10.00 & 10.00 & $\begin{array}{r}4 . \\
7 \\
0\end{array}$ & 0.02 & 4.00 & 52.50 & 25.00 & $\begin{array}{r}71 \\
.9 \\
2 \\
\end{array}$ & 754.23 \\
\hline
\end{tabular}




\begin{tabular}{|c|c|c|c|c|c|c|c|c|c|c|c|c|}
\hline 455.54 & $\begin{array}{r}4 . \\
19\end{array}$ & 0.002 & 19.47 & 10.00 & 10.00 & $\begin{array}{c}4 . \\
7 \\
0\end{array}$ & 0.02 & 2.00 & 52.50 & 25.00 & $\begin{array}{r}57 \\
.4 \\
6\end{array}$ & 674.65 \\
\hline 455.54 & $\begin{array}{r}4 . \\
19\end{array}$ & 0.002 & 19.47 & 10.00 & 10.00 & $\begin{array}{l}4 . \\
7 \\
0\end{array}$ & 0.02 & 2.00 & 52.50 & 25.00 & $\begin{array}{r}78 \\
.9 \\
1\end{array}$ & 678.64 \\
\hline 455.54 & $\begin{array}{r}4 . \\
19\end{array}$ & 0.002 & 19.47 & 10.00 & 10.00 & $\begin{array}{l}4 . \\
7 \\
0 \\
\end{array}$ & 0.02 & 1.00 & 45.00 & 25.00 & $\begin{array}{r}33 \\
.3 \\
9\end{array}$ & 715.98 \\
\hline 455.54 & $\begin{array}{r}4 . \\
19\end{array}$ & 0.002 & 19.47 & 10.00 & 10.00 & $\begin{array}{r}4 . \\
7 \\
0 \\
\end{array}$ & 0.02 & 2.00 & 60.00 & 25.00 & $\begin{array}{r}40 \\
.1 \\
9 \\
\end{array}$ & 586.67 \\
\hline 455.54 & $\begin{array}{r}4 . \\
19\end{array}$ & 0.002 & 19.47 & 10.00 & 10.00 & $\begin{array}{r}4 . \\
7 \\
0\end{array}$ & 0.01 & 6.00 & 52.50 & 25.00 & $\begin{array}{r}94 \\
.7 \\
5\end{array}$ & 605.87 \\
\hline 455.54 & $\begin{array}{r}4 . \\
19\end{array}$ & 0.002 & 19.47 & 10.00 & 10.00 & $\begin{array}{r}4 . \\
7 \\
0\end{array}$ & 0.01 & 3.00 & 52.50 & 25.00 & $\begin{array}{r}58 \\
.6 \\
7\end{array}$ & 583.65 \\
\hline 455.54 & $\begin{array}{r}4 . \\
19\end{array}$ & 0.002 & 19.47 & 10.00 & 10.00 & $\begin{array}{r}4 . \\
7 \\
0 \\
\end{array}$ & 0.02 & 2.00 & 45.00 & 25.00 & $\begin{array}{r}48 \\
.4 \\
2 \\
\end{array}$ & 643.82 \\
\hline 455.54 & $\begin{array}{r}4 . \\
19\end{array}$ & 0.002 & 19.47 & 10.00 & 10.00 & $\begin{array}{r}4 . \\
7 \\
0 \\
\end{array}$ & 0.02 & 2.00 & 52.50 & 25.00 & $\begin{array}{r}76 \\
.8 \\
5 \\
\end{array}$ & 672.97 \\
\hline 455.54 & $\begin{array}{r}4 . \\
19\end{array}$ & 0.002 & 19.47 & 10.00 & 10.00 & $\begin{array}{r}4 . \\
7 \\
0 \\
\end{array}$ & 0.02 & 4.00 & 45.00 & 25.00 & $\begin{array}{r}66 \\
.2 \\
8 \\
\end{array}$ & 613.98 \\
\hline 455.54 & $\begin{array}{r}4 . \\
19\end{array}$ & 0.002 & 19.47 & 10.00 & 10.00 & $\begin{array}{l}4 . \\
7 \\
0\end{array}$ & 0.01 & 1.33 & 52.50 & 25.00 & $\begin{array}{r}30 \\
.9 \\
3\end{array}$ & 788.42 \\
\hline 455.54 & $\begin{array}{r}4 . \\
19\end{array}$ & 0.002 & 19.47 & 10.00 & 10.00 & $\begin{array}{r}4 . \\
7 \\
0 \\
\end{array}$ & 0.01 & 3.00 & 52.50 & 25.00 & $\begin{array}{r}58 \\
.9 \\
8 \\
\end{array}$ & 697.92 \\
\hline 455.54 & $\begin{array}{r}4 . \\
19\end{array}$ & 0.002 & 19.47 & 10.00 & 10.00 & $\begin{array}{l}4 . \\
7 \\
0\end{array}$ & 0.02 & 2.00 & 45.00 & 25.00 & $\begin{array}{r}39 \\
.4 \\
2\end{array}$ & 737.76 \\
\hline 455.54 & $\begin{array}{r}4 . \\
19\end{array}$ & 0.002 & 19.47 & 10.00 & 10.00 & $\begin{array}{r}4 . \\
7 \\
0\end{array}$ & 0.02 & 0.67 & 52.50 & 25.00 & $\begin{array}{r}36 \\
.6 \\
8 \\
\end{array}$ & 760.38 \\
\hline 455.54 & $\begin{array}{r}4 . \\
19\end{array}$ & 0.002 & 19.47 & 10.00 & 10.00 & $\begin{array}{r}4 . \\
7 \\
0\end{array}$ & 0.01 & 2.00 & 52.50 & 25.00 & $\begin{array}{r}44 \\
.0 \\
1 \\
\end{array}$ & 624.34 \\
\hline 455.54 & $\begin{array}{r}4 . \\
19\end{array}$ & 0.002 & 19.47 & 10.00 & 10.00 & $\begin{array}{r}4 . \\
7 \\
0\end{array}$ & 0.02 & 4.00 & 60.00 & 25.00 & $\begin{array}{r}66 \\
.8 \\
5 \\
\end{array}$ & 648.45 \\
\hline 455.54 & $\begin{array}{r}4 . \\
19\end{array}$ & 0.002 & 19.47 & 10.00 & 10.00 & $\begin{array}{r}4 . \\
7 \\
0\end{array}$ & 0.02 & 2.00 & 60.00 & 25.00 & $\begin{array}{r}51 \\
.6 \\
3\end{array}$ & 743.67 \\
\hline 455.54 & $\begin{array}{r}4 . \\
19\end{array}$ & 0.002 & 19.47 & 10.00 & 10.00 & $\begin{array}{r}4 . \\
7 \\
0\end{array}$ & 0.02 & 2.00 & 52.50 & 25.00 & $\begin{array}{r}80 \\
.5 \\
4\end{array}$ & 682.98 \\
\hline 455.54 & $\begin{array}{r}4 . \\
19\end{array}$ & 0.002 & 19.47 & 10.00 & 10.00 & $\begin{array}{r}4 . \\
7 \\
0 \\
\end{array}$ & 0.01 & 1.33 & 52.50 & 25.00 & $\begin{array}{r}31 \\
.7 \\
0 \\
\end{array}$ & 665.98 \\
\hline 455.54 & $\begin{array}{r}4 . \\
19\end{array}$ & 0.002 & 19.47 & 10.00 & 10.00 & $\begin{array}{l}4 . \\
7 \\
0\end{array}$ & 0.01 & 1.33 & 45.00 & 25.00 & $\begin{array}{r}30 \\
.9 \\
3 \\
\end{array}$ & 712.57 \\
\hline 455.54 & $\begin{array}{r}4 . \\
19\end{array}$ & 0.002 & 19.47 & 10.00 & 10.00 & $\begin{array}{r}4 . \\
7 \\
0\end{array}$ & 0.01 & 3.00 & 60.00 & 25.00 & $\begin{array}{r}62 \\
.6 \\
2 \\
\end{array}$ & 605.39 \\
\hline 455.54 & $\begin{array}{r}4 . \\
19\end{array}$ & 0.002 & 19.47 & 10.00 & 10.00 & $\begin{array}{r}4 . \\
7 \\
0 \\
\end{array}$ & 0.02 & 1.00 & 52.50 & 25.00 & $\begin{array}{r}39 \\
.9 \\
9 \\
\end{array}$ & 812.45 \\
\hline 455.54 & $\begin{array}{r}4 . \\
19\end{array}$ & 0.002 & 19.47 & 10.00 & 10.00 & $\begin{array}{l}4 . \\
7 \\
0\end{array}$ & 0.02 & 2.00 & 52.50 & 25.00 & $\begin{array}{r}82 \\
.7 \\
7 \\
\end{array}$ & 676.98 \\
\hline 455.54 & 4. & 0.002 & 19.47 & 10.00 & 10.00 & 4. & 0.02 & 1.00 & 52.50 & 25.00 & 34 & 673.98 \\
\hline
\end{tabular}




\begin{tabular}{|c|c|c|c|c|c|c|c|c|c|c|c|c|}
\hline & 19 & & & & & $\begin{array}{l}7 \\
0 \\
\end{array}$ & & & & & $\begin{array}{l}.9 \\
2 \\
\end{array}$ & \\
\hline 455.54 & $\begin{array}{r}4 . \\
19\end{array}$ & 0.002 & 19.47 & 10.00 & 10.00 & $\begin{array}{r}4 . \\
7 \\
0\end{array}$ & 0.01 & 3.00 & 45.00 & 25.00 & $\begin{array}{r}57 \\
.9 \\
3\end{array}$ & 589.65 \\
\hline 455.54 & $\begin{array}{r}4 . \\
19\end{array}$ & 0.002 & 19.47 & 10.00 & 10.00 & $\begin{array}{l}4 . \\
7 \\
0\end{array}$ & 0.02 & 1.00 & 60.00 & 25.00 & $\begin{array}{r}36 \\
.8 \\
2\end{array}$ & 653.76 \\
\hline 455.54 & $\begin{array}{r}4 . \\
19\end{array}$ & 0.002 & 19.47 & 10.00 & 10.00 & $\begin{array}{r}4 . \\
7 \\
0\end{array}$ & 0.03 & 2.00 & 52.50 & 25.00 & $\begin{array}{r}58 \\
.8 \\
7\end{array}$ & 662.67 \\
\hline 455.54 & $\begin{array}{r}4 . \\
19\end{array}$ & 0.002 & 19.47 & 10.00 & 10.00 & $\begin{array}{r}4 . \\
7 \\
0\end{array}$ & 0.02 & 4.00 & 52.50 & 25.00 & $\begin{array}{r}64 \\
.8 \\
2 \\
\end{array}$ & 598.71 \\
\hline 455.54 & $\begin{array}{r}4 . \\
19\end{array}$ & 0.002 & 19.47 & 10.00 & 10.00 & $\begin{array}{l}4 . \\
7 \\
0\end{array}$ & 0.01 & 1.33 & 60.00 & 25.00 & $\begin{array}{r}31 \\
.3 \\
2\end{array}$ & 628.49 \\
\hline 531.43 & $\begin{array}{r}4 . \\
35\end{array}$ & 0.000 & 6.75 & 20.00 & 10.00 & $\begin{array}{r}4 . \\
7 \\
0 \\
\end{array}$ & 0.83 & 0.20 & 60.00 & 60.00 & $\begin{array}{r}69 \\
.3 \\
9 \\
\end{array}$ & 5940.00 \\
\hline 531.43 & $\begin{array}{r}4 . \\
35\end{array}$ & 0.000 & 6.75 & 20.00 & 10.00 & $\begin{array}{r}4 . \\
7 \\
0 \\
\end{array}$ & 0.56 & 0.20 & 60.00 & 60.00 & $\begin{array}{r}73 \\
.4 \\
8 \\
\end{array}$ & 5220.00 \\
\hline 531.43 & $\begin{array}{r}4 . \\
35\end{array}$ & 0.000 & 6.75 & 20.00 & 10.00 & $\begin{array}{r}4 . \\
7 \\
0 \\
\end{array}$ & 0.42 & 0.20 & 60.00 & 60.00 & $\begin{array}{r}76 \\
.9 \\
6 \\
\end{array}$ & 4860.00 \\
\hline 329.80 & $\begin{array}{r}2 . \\
35\end{array}$ & 0.248 & 15.39 & 10.00 & 15.00 & $\begin{array}{l}4 . \\
7 \\
0\end{array}$ & 0.33 & 0.50 & 60.00 & 60.00 & $\begin{array}{r}54 \\
.8 \\
3 \\
\end{array}$ & 196.15 \\
\hline 329.80 & $\begin{array}{r}2 . \\
35\end{array}$ & 0.248 & 15.39 & 10.00 & 15.00 & $\begin{array}{r}4 . \\
7 \\
0 \\
\end{array}$ & 0.33 & 1.00 & 60.00 & 60.00 & $\begin{array}{r}76 \\
.1 \\
3 \\
\end{array}$ & 249.80 \\
\hline 329.80 & $\begin{array}{r}2 . \\
35\end{array}$ & 0.248 & 15.39 & 10.00 & 15.00 & $\begin{array}{r}4 . \\
7 \\
0\end{array}$ & 0.33 & 2.00 & 60.00 & 60.00 & $\begin{array}{r}50 \\
.5 \\
6\end{array}$ & 2486.00 \\
\hline 316.42 & $\begin{array}{r}1 . \\
34\end{array}$ & 0.269 & 14.08 & 10.00 & 10.00 & $\begin{array}{r}4 . \\
7 \\
0\end{array}$ & 0.08 & 0.38 & 60.00 & 60.00 & $\begin{array}{r}94 \\
.6 \\
0\end{array}$ & 80.35 \\
\hline 323.41 & $\begin{array}{r}1 . \\
52\end{array}$ & 0.19 & 4.07 & 10.00 & 10.00 & $\begin{array}{r}4 . \\
7 \\
0 \\
\end{array}$ & 0.79 & 0.20 & 60.00 & 25.00 & $\begin{array}{r}75 \\
.1 \\
0 \\
\end{array}$ & $\begin{array}{r}12340.0 \\
0 \\
\end{array}$ \\
\hline 323.41 & $\begin{array}{r}1 . \\
52\end{array}$ & 0.19 & 4.07 & 10.00 & 10.00 & $\begin{array}{r}4 . \\
7 \\
0 \\
\end{array}$ & 0.79 & 0.33 & 60.00 & 25.00 & $\begin{array}{r}78 \\
.8 \\
5 \\
\end{array}$ & $\begin{array}{r}13230.0 \\
0 \\
\end{array}$ \\
\hline 323.41 & $\begin{array}{r}1 . \\
52\end{array}$ & 0.19 & 4.07 & 10.00 & 10.00 & $\begin{array}{r}4 . \\
7 \\
0 \\
\end{array}$ & 0.80 & 0.50 & 60.00 & 25.00 & $\begin{array}{r}81 \\
.0 \\
7 \\
\end{array}$ & $\begin{array}{r}15340.0 \\
0 \\
\end{array}$ \\
\hline 323.41 & $\begin{array}{r}1 . \\
52\end{array}$ & 0.19 & 4.07 & 10.00 & 10.00 & $\begin{array}{l}4 . \\
7 \\
0\end{array}$ & 0.88 & 0.57 & 60.00 & 25.00 & $\begin{array}{r}86 \\
.1 \\
0 \\
\end{array}$ & $\begin{array}{r}15650.0 \\
0\end{array}$ \\
\hline 323.41 & $\begin{array}{r}1 . \\
52\end{array}$ & 0.19 & 4.07 & 10.00 & 10.00 & $\begin{array}{r}4 . \\
7 \\
0 \\
\end{array}$ & 0.91 & 0.51 & 60.00 & 25.00 & $\begin{array}{r}71 \\
.8 \\
9 \\
\end{array}$ & $\begin{array}{r}14320.0 \\
0 \\
\end{array}$ \\
\hline 323.41 & $\begin{array}{r}1 . \\
52\end{array}$ & 0.19 & 4.07 & 10.00 & 10.00 & $\begin{array}{l}4 . \\
7 \\
0\end{array}$ & 0.96 & 0.43 & 60.00 & 25.00 & $\begin{array}{r}68 \\
.1 \\
0 \\
\end{array}$ & $\begin{array}{r}13780.0 \\
0\end{array}$ \\
\hline 323.41 & $\begin{array}{r}1 . \\
52\end{array}$ & 0.19 & 4.07 & 10.00 & 10.00 & $\begin{array}{r}4 . \\
7 \\
0\end{array}$ & 1.19 & 0.33 & 60.00 & 25.00 & $\begin{array}{r}67 \\
.8 \\
6\end{array}$ & $\begin{array}{r}12730.0 \\
0\end{array}$ \\
\hline 352.76 & $\begin{array}{c}2 . \\
18\end{array}$ & 0.009 & 17.69 & 10.00 & 10.00 & $\begin{array}{r}4 . \\
7 \\
0 \\
\end{array}$ & 2.00 & 0.20 & 45.00 & 60.00 & $\begin{array}{r}69 \\
.2 \\
6 \\
\end{array}$ & 3990.00 \\
\hline 352.76 & $\begin{array}{c}2 . \\
18\end{array}$ & 0.009 & 17.69 & 10.00 & 10.00 & $\begin{array}{r}4 . \\
7 \\
0 \\
\end{array}$ & 2.00 & 0.50 & 45.00 & 60.00 & $\begin{array}{r}72 \\
.4 \\
0 \\
\end{array}$ & 4180.00 \\
\hline 352.76 & $\begin{array}{r}2 . \\
18\end{array}$ & 0.009 & 17.69 & 10.00 & 10.00 & $\begin{array}{r}4 . \\
7\end{array}$ & 2.00 & 1.00 & 45.00 & 60.00 & $\begin{array}{c}76 \\
.8\end{array}$ & 4370.00 \\
\hline
\end{tabular}




\begin{tabular}{|c|c|c|c|c|c|c|c|c|c|c|c|c|}
\hline 635.50 & $\begin{array}{r}2 . \\
65\end{array}$ & 0.712 & 18.59 & 10.00 & 10.00 & $\begin{array}{r}4 . \\
7 \\
0 \\
\end{array}$ & 0.50 & 0.40 & 180.00 & 60.00 & $\begin{array}{r}48 \\
.0 \\
0 \\
\end{array}$ & 3980.00 \\
\hline 635.50 & $\begin{array}{r}2 . \\
65\end{array}$ & 0.712 & 18.59 & 10.00 & 10.00 & $\begin{array}{r}4 . \\
7 \\
0\end{array}$ & 0.50 & 0.50 & 180.00 & 60.00 & $\begin{array}{r}59 \\
.0 \\
0\end{array}$ & 4310.00 \\
\hline 635.50 & $\begin{array}{r}2 . \\
65\end{array}$ & 0.712 & 18.59 & 10.00 & 10.00 & $\begin{array}{r}4 \\
7 \\
0\end{array}$ & 0.50 & 0.67 & 180.00 & 60.00 & $\begin{array}{r}71 \\
.0 \\
0\end{array}$ & 4930.00 \\
\hline 635.50 & $\begin{array}{r}2 . \\
65\end{array}$ & 0.712 & 18.59 & 10.00 & 10.00 & $\begin{array}{r}4 . \\
7 \\
0 \\
\end{array}$ & 0.50 & 1.00 & 180.00 & 60.00 & $\begin{array}{r}95 \\
.0 \\
0 \\
\end{array}$ & 6820.00 \\
\hline 635.50 & $\begin{array}{r}2 . \\
65\end{array}$ & 0.712 & 18.59 & 10.00 & 10.00 & $\begin{array}{r}4 . \\
7 \\
0\end{array}$ & 0.50 & 1.50 & 180.00 & 60.00 & $\begin{array}{r}89 \\
.0 \\
0\end{array}$ & 8550.00 \\
\hline 159.23 & $\begin{array}{r}- \\
1 . \\
30\end{array}$ & 11.30 & 4.80 & 10.00 & 10.00 & $\begin{array}{r}4 . \\
7 \\
0\end{array}$ & 0.25 & 0.25 & 5.00 & 40.00 & $\begin{array}{r}37 \\
.6 \\
4\end{array}$ & $\begin{array}{r}23010.0 \\
0\end{array}$ \\
\hline 159.23 & $\begin{array}{r}- \\
1 . \\
30\end{array}$ & 11.30 & 4.80 & 20.00 & 10.00 & $\begin{array}{l}4 . \\
7 \\
0\end{array}$ & 0.25 & 0.25 & 5.00 & 40.00 & $\begin{array}{r}36 \\
.8 \\
3 \\
\end{array}$ & $\begin{array}{r}22340.0 \\
0\end{array}$ \\
\hline 159.23 & $\begin{array}{r}- \\
1 . \\
30\end{array}$ & 11.30 & 4.80 & 15.00 & 10.00 & $\begin{array}{r}4 . \\
7 \\
0 \\
\end{array}$ & 0.25 & 1.00 & 5.00 & 40.00 & $\begin{array}{r}45 \\
.1 \\
8 \\
\end{array}$ & $\begin{array}{r}40800.0 \\
0\end{array}$ \\
\hline 159.23 & $\begin{array}{r}- \\
1 . \\
30\end{array}$ & 11.30 & 4.80 & 10.00 & 10.00 & $\begin{array}{l}4 . \\
7 \\
0\end{array}$ & 0.25 & 1.75 & 5.00 & 40.00 & $\begin{array}{r}56 \\
.2 \\
3 \\
\end{array}$ & $\begin{array}{r}58830.0 \\
0\end{array}$ \\
\hline 159.23 & $\begin{array}{r}- \\
1 . \\
30\end{array}$ & 11.30 & 4.80 & 20.00 & 10.00 & $\begin{array}{r}4 . \\
7 \\
0\end{array}$ & 0.25 & 1.75 & 5.00 & 40.00 & $\begin{array}{r}56 \\
.8 \\
7\end{array}$ & $\begin{array}{r}59120.0 \\
0\end{array}$ \\
\hline 337.45 & $\begin{array}{r}- \\
0 . \\
64 \\
\end{array}$ & 11.30 & 9.29 & 5.00 & 20.00 & $\begin{array}{r}4 . \\
7 \\
0 \\
\end{array}$ & 0.24 & 1.00 & 10.00 & 25.00 & $\begin{array}{r}66 \\
.1 \\
6 \\
\end{array}$ & 3200.00 \\
\hline 337.45 & $\begin{array}{r}- \\
0 . \\
64 \\
\end{array}$ & 11.30 & 9.29 & 5.00 & 20.00 & $\begin{array}{r}4 . \\
7 \\
0 \\
\end{array}$ & 0.20 & 1.00 & 10.00 & 25.00 & $\begin{array}{r}67 \\
.8 \\
2 \\
\end{array}$ & 3080.00 \\
\hline 337.45 & $\begin{array}{r}- \\
0 . \\
64\end{array}$ & 11.30 & 9.29 & 5.00 & 20.00 & $\begin{array}{r}4 \\
7 \\
0\end{array}$ & 0.19 & 0.67 & 10.00 & 25.00 & $\begin{array}{r}68 \\
.9 \\
6\end{array}$ & 3100.00 \\
\hline 418.56 & $\begin{array}{r}4 . \\
68\end{array}$ & 0.012 & 14.91 & 10.00 & 10.00 & $\begin{array}{r}4 . \\
7 \\
0\end{array}$ & 0.09 & 1.50 & 60.00 & 60.00 & $\begin{array}{r}90 \\
.2 \\
7 \\
\end{array}$ & 432.10 \\
\hline 418.56 & $\begin{array}{r}4 . \\
68\end{array}$ & 0.012 & 14.91 & 10.00 & 10.00 & $\begin{array}{r}4 . \\
7 \\
0 \\
\end{array}$ & 0.09 & 1.50 & 60.00 & 60.00 & $\begin{array}{r}86 \\
.3 \\
9 \\
\end{array}$ & 365.70 \\
\hline 418.56 & $\begin{array}{r}4 \\
68\end{array}$ & 0.012 & 14.91 & 10.00 & 10.00 & $\begin{array}{r}4 . \\
7 \\
0 \\
\end{array}$ & 0.15 & 0.67 & 60.00 & 60.00 & $\begin{array}{r}96 \\
.2 \\
0 \\
\end{array}$ & 290.30 \\
\hline 418.56 & $\begin{array}{r}4 . \\
68\end{array}$ & 0.012 & 14.91 & 10.00 & 10.00 & $\begin{array}{r}4 . \\
7 \\
0\end{array}$ & 0.19 & 0.25 & 60.00 & 60.00 & $\begin{array}{r}95 \\
.8 \\
4 \\
\end{array}$ & 326.70 \\
\hline 418.56 & $\begin{array}{r}4 . \\
68\end{array}$ & 0.012 & 14.91 & 10.00 & 10.00 & $\begin{array}{r}4 . \\
7 \\
0 \\
\end{array}$ & 0.15 & 0.67 & 60.00 & 60.00 & $\begin{array}{r}96 \\
.9 \\
0 \\
\end{array}$ & 320.10 \\
\hline 418.56 & $\begin{array}{r}4 . \\
68\end{array}$ & 0.012 & 14.91 & 10.00 & 10.00 & $\begin{array}{r}4 . \\
7 \\
0 \\
\end{array}$ & 0.19 & 0.25 & 60.00 & 60.00 & $\begin{array}{r}94 \\
.3 \\
2 \\
\end{array}$ & 194.20 \\
\hline 418.56 & $\begin{array}{r}4 . \\
68\end{array}$ & 0.012 & 14.91 & 10.00 & 10.00 & $\begin{array}{r}4 \\
7 \\
0\end{array}$ & 0.09 & 1.50 & 60.00 & 60.00 & $\begin{array}{r}87 \\
.6 \\
9\end{array}$ & 390.20 \\
\hline 418.56 & $\begin{array}{r}4 . \\
68\end{array}$ & 0.012 & 14.91 & 10.00 & 10.00 & $\begin{array}{r}4 . \\
7 \\
0 \\
\end{array}$ & 0.15 & 0.67 & 60.00 & 60.00 & $\begin{array}{r}95 \\
.3 \\
4 \\
\end{array}$ & 270.40 \\
\hline 418.56 & $\begin{array}{r}4 . \\
68\end{array}$ & 0.012 & 14.91 & 10.00 & 10.00 & $\begin{array}{r}4 . \\
7 \\
0 \\
\end{array}$ & 0.15 & 0.25 & 60.00 & 60.00 & $\begin{array}{r}94 \\
.3 \\
2 \\
\end{array}$ & 220.50 \\
\hline
\end{tabular}




\begin{tabular}{|c|c|c|c|c|c|c|c|c|c|c|c|c|}
\hline 318.10 & $\begin{array}{r}4 . \\
26\end{array}$ & 0.005 & 4.00 & 15.00 & 20.00 & $\begin{array}{c}4 . \\
7 \\
0\end{array}$ & 0.37 & 1.00 & 5.00 & 25.00 & $\begin{array}{r}91 \\
.4 \\
3\end{array}$ & 892.40 \\
\hline 318.10 & $\begin{array}{r}4 . \\
26\end{array}$ & 0.005 & 4.00 & 15.00 & 20.00 & $\begin{array}{l}4 . \\
7 \\
0\end{array}$ & 0.74 & 0.67 & 5.00 & 25.00 & $\begin{array}{r}92 \\
.5 \\
3 \\
\end{array}$ & 813.00 \\
\hline 318.10 & $\begin{array}{r}4 . \\
26\end{array}$ & 0.005 & 4.00 & 15.00 & 20.00 & $\begin{array}{l}4 . \\
7 \\
0 \\
\end{array}$ & 0.38 & 0.43 & 5.00 & 25.00 & $\begin{array}{r}92 \\
.3 \\
3\end{array}$ & 311.60 \\
\hline 236.27 & $\begin{array}{r}2 . \\
77\end{array}$ & 0.125 & 15.96 & 10.00 & 10.00 & $\begin{array}{r}4 . \\
7 \\
0 \\
\end{array}$ & 0.50 & 1.00 & 20.00 & 50.00 & $\begin{array}{r}83 \\
.5 \\
0 \\
\end{array}$ & 4200.00 \\
\hline 236.27 & $\begin{array}{r}2 . \\
77\end{array}$ & 0.125 & 15.96 & 10.00 & 10.00 & $\begin{array}{r}4 . \\
7 \\
0 \\
\end{array}$ & 0.33 & 0.50 & 20.00 & 50.00 & $\begin{array}{r}89 \\
.1 \\
0 \\
\end{array}$ & 4300.00 \\
\hline 129.16 & $\begin{array}{r}- \\
1 . \\
80 \\
\end{array}$ & 50.000 & 12.33 & 5.00 & 10.00 & $\begin{array}{r}4 . \\
7 \\
0\end{array}$ & 0.24 & 1.00 & 60.00 & 50.00 & $\begin{array}{r}85 \\
.1 \\
6 \\
\end{array}$ & 574.33 \\
\hline 129.16 & $\begin{array}{r}- \\
1 . \\
80 \\
\end{array}$ & 50.000 & 12.33 & 5.00 & 10.00 & $\begin{array}{r}4 . \\
7 \\
0 \\
\end{array}$ & 0.24 & 1.00 & 60.00 & 50.00 & $\begin{array}{r}87 \\
.1 \\
2 \\
\end{array}$ & 636.00 \\
\hline 129.16 & $\begin{array}{r}- \\
1 . \\
80 \\
\end{array}$ & 50.000 & 12.33 & 5.00 & 10.00 & $\begin{array}{r}4 . \\
7 \\
0 \\
\end{array}$ & 0.58 & 1.00 & 60.00 & 50.00 & $\begin{array}{r}84 \\
.5 \\
0 \\
\end{array}$ & 487.60 \\
\hline 129.16 & $\begin{array}{r}- \\
1 . \\
80 \\
\end{array}$ & 50.000 & 12.33 & 5.00 & 10.00 & $\begin{array}{l}4 . \\
7 \\
0 \\
\end{array}$ & 0.61 & 1.00 & 60.00 & 50.00 & $\begin{array}{r}86 \\
.5 \\
1 \\
\end{array}$ & 504.66 \\
\hline 129.16 & $\begin{array}{r}- \\
1 . \\
80\end{array}$ & 50.000 & 12.33 & 5.00 & 10.00 & $\begin{array}{l}4 . \\
7 \\
0\end{array}$ & 0.75 & 1.00 & 60.00 & 50.00 & $\begin{array}{r}83 \\
.6 \\
6 \\
\end{array}$ & 388.00 \\
\hline 129.16 & $\begin{array}{r}- \\
1 . \\
80 \\
\end{array}$ & 50.000 & 12.33 & 5.00 & 10.00 & $\begin{array}{r}4 . \\
7 \\
0 \\
\end{array}$ & 0.82 & 1.00 & 60.00 & 50.00 & $\begin{array}{r}84 \\
.7 \\
1 \\
\end{array}$ & 496.66 \\
\hline 129.16 & $\begin{array}{r}- \\
1 . \\
80 \\
\end{array}$ & 50.000 & 12.33 & 15.00 & 10.00 & $\begin{array}{r}4 . \\
7 \\
0 \\
\end{array}$ & 0.70 & 1.00 & 60.00 & 50.00 & $\begin{array}{r}78 \\
.8 \\
4 \\
\end{array}$ & 565.33 \\
\hline 129.16 & $\begin{array}{r}- \\
1 . \\
80 \\
\end{array}$ & 50.000 & 12.33 & 15.00 & 10.00 & $\begin{array}{r}4 . \\
7 \\
0\end{array}$ & 0.61 & 1.00 & 60.00 & 50.00 & $\begin{array}{r}84 \\
.1 \\
4\end{array}$ & 624.67 \\
\hline 129.16 & $\begin{array}{r}- \\
1 . \\
80 \\
\end{array}$ & 50.000 & 12.33 & 15.00 & 10.00 & $\begin{array}{r}4 . \\
7 \\
0\end{array}$ & 0.54 & 1.00 & 60.00 & 50.00 & $\begin{array}{r}79 \\
.2 \\
7 \\
\end{array}$ & 462.33 \\
\hline 129.16 & $\begin{array}{r}- \\
1 . \\
80 \\
\end{array}$ & 50.000 & 12.33 & 10.00 & 10.00 & $\begin{array}{r}4 . \\
7 \\
0 \\
\end{array}$ & 0.61 & 1.00 & 60.00 & 50.00 & $\begin{array}{r}66 \\
.9 \\
2 \\
\end{array}$ & 496.33 \\
\hline 129.16 & $\begin{array}{r}- \\
1 . \\
80 \\
\end{array}$ & 50.000 & 12.33 & 15.00 & 10.00 & $\begin{array}{l}4 . \\
7 \\
0 \\
\end{array}$ & 0.61 & 1.00 & 60.00 & 50.00 & $\begin{array}{r}83 \\
.3 \\
7 \\
\end{array}$ & 378.67 \\
\hline 129.16 & $\begin{array}{r}- \\
1 . \\
80 \\
\end{array}$ & 50.000 & 12.33 & 20.00 & 10.00 & $\begin{array}{r}4 . \\
7 \\
0\end{array}$ & 0.61 & 1.00 & 60.00 & 50.00 & $\begin{array}{r}79 \\
.3 \\
6 \\
\end{array}$ & 484.67 \\
\hline 129.16 & $\begin{array}{r}- \\
1 . \\
80 \\
\end{array}$ & 50.000 & 12.33 & 15.00 & 10.00 & $\begin{array}{r}4 . \\
7 \\
0 \\
\end{array}$ & 0.70 & 1.33 & 60.00 & 50.00 & $\begin{array}{r}78 \\
.8 \\
4 \\
\end{array}$ & 524.33 \\
\hline 129.16 & $\begin{array}{r}- \\
1 . \\
80 \\
\end{array}$ & 50.000 & 12.33 & 15.00 & 10.00 & $\begin{array}{r}4 . \\
7 \\
0 \\
\end{array}$ & 0.61 & 1.00 & 60.00 & 50.00 & $\begin{array}{r}84 \\
.1 \\
4 \\
\end{array}$ & 481.33 \\
\hline 129.16 & $\begin{array}{r}- \\
1 . \\
80 \\
\end{array}$ & 50.000 & 12.33 & 15.00 & 10.00 & $\begin{array}{r}4 . \\
7 \\
0 \\
\end{array}$ & 0.54 & 0.80 & 60.00 & 50.00 & $\begin{array}{r}79 \\
.2 \\
7 \\
\end{array}$ & 445.33 \\
\hline 129.16 & $\begin{array}{r}- \\
1 . \\
80 \\
\end{array}$ & 50.000 & 12.33 & 10.00 & 10.00 & $\begin{array}{r}4 . \\
7 \\
0 \\
\end{array}$ & 0.61 & 1.00 & 60.00 & 50.00 & $\begin{array}{r}66 \\
.9 \\
2 \\
\end{array}$ & 490.67 \\
\hline 129.16 & $\begin{array}{r}- \\
1 . \\
80 \\
\end{array}$ & 50.000 & 12.33 & 15.00 & 10.00 & $\begin{array}{l}4 . \\
7 \\
0 \\
\end{array}$ & 0.61 & 1.00 & 60.00 & 50.00 & $\begin{array}{r}83 \\
.3 \\
7 \\
\end{array}$ & 477.33 \\
\hline 129.16 & - & 50.000 & 12.33 & 20.00 & 10.00 & 4. & 0.61 & 1.00 & 60.00 & 50.00 & 79 & 455.00 \\
\hline
\end{tabular}




\begin{tabular}{|c|c|c|c|c|c|c|c|c|c|c|c|c|}
\hline & $\begin{array}{r}1 . \\
80 \\
\end{array}$ & & & & & $\begin{array}{l}7 \\
0 \\
\end{array}$ & & & & & $\begin{array}{r}.3 \\
6 \\
\end{array}$ & \\
\hline 354.18 & $\begin{array}{c}3 . \\
88\end{array}$ & 0.000 & 3.44 & 10.00 & 10.00 & $\begin{array}{r}4 . \\
7 \\
0\end{array}$ & 1.13 & 0.57 & 60.00 & 60.00 & $\begin{array}{r}31 \\
.6 \\
0\end{array}$ & 850.00 \\
\hline 354.18 & $\begin{array}{c}3 . \\
88\end{array}$ & 0.000 & 3.44 & 10.00 & 10.00 & $\begin{array}{l}4 . \\
7 \\
0\end{array}$ & 0.95 & 0.86 & 60.00 & 60.00 & $\begin{array}{r}45 \\
.1 \\
0\end{array}$ & 890.00 \\
\hline 354.18 & $\begin{array}{c}3 . \\
88\end{array}$ & 0.000 & 3.44 & 10.00 & 10.00 & $\begin{array}{r}4 . \\
7 \\
0 \\
\end{array}$ & 0.87 & 1.00 & 60.00 & 60.00 & $\begin{array}{r}37 \\
.9 \\
0 \\
\end{array}$ & 1040.00 \\
\hline 314.36 & $\begin{array}{c}3 . \\
20\end{array}$ & 0.472 & 14.84 & 5.00 & 10.00 & $\begin{array}{r}4 . \\
7 \\
0\end{array}$ & 0.05 & 1.00 & 60.00 & 25.00 & $\begin{array}{r}23 \\
.2 \\
3\end{array}$ & $\begin{array}{r}10360.0 \\
0\end{array}$ \\
\hline 314.36 & $\begin{array}{c}3 . \\
20\end{array}$ & 0.472 & 14.84 & 5.00 & 10.00 & $\begin{array}{r}4 . \\
7 \\
0 \\
\end{array}$ & 0.06 & 1.00 & 60.00 & 25.00 & $\begin{array}{r}21 \\
.6 \\
3 \\
\end{array}$ & $\begin{array}{r}10160.0 \\
0\end{array}$ \\
\hline 314.36 & $\begin{array}{c}3 . \\
20\end{array}$ & 0.472 & 14.84 & 5.00 & 10.00 & $\begin{array}{r}4 . \\
7 \\
0\end{array}$ & 0.05 & 0.67 & 60.00 & 25.00 & $\begin{array}{r}28 \\
.1 \\
0\end{array}$ & $\begin{array}{r}10550.0 \\
0\end{array}$ \\
\hline
\end{tabular}

